Review

\title{
Integrated Lipidomics in the Secreted Phospholipase A Biology
}

\section{Makoto Murakami *, Hiroyasu Sato, Yoshitaka Taketomi and Kei Yamamoto}

Lipid Metabolism Project, The Tokyo Metropolitan Institute of Medical Science, 2-1-6 Kamikitazawa, Setagaya-ku, Tokyo 156-8506, Japan; E-Mails: sato-hr@igakuken.or.jp (H.S.);

taketomi-ys@igakuken.or.jp (Y.T.); and yamamoto-ki@igakuken.or.jp (K.Y.)

* Author to whom correspondence should be addressed; E-Mail: murakami-mk@igakuken.or.jp; Tel.: +81-3-5316-3228.

Received: 30 January 2011; in revised form: 18 February 2011 / Accepted: 24 February 2011 / Published: 25 February 2011

Abstract: Mammalian genomes encode genes for more than 30 phospholipase $A_{2} S$ $\left(\mathrm{PLA}_{2} \mathrm{~S}\right)$ or related enzymes, which are subdivided into several subgroups based on their structures, catalytic mechanisms, localizations and evolutionary relationships. More than one third of the $\mathrm{PLA}_{2}$ enzymes belong to the secreted PLA $2\left(\mathrm{sPLA}_{2}\right)$ family, which consists of low-molecular-weight, $\mathrm{Ca}^{2+}$-requiring extracellular enzymes, with a His-Asp catalytic dyad. Individual $\mathrm{sPLA}_{2}$ isoforms exhibit unique tissue and cellular localizations and enzymatic properties, suggesting their distinct pathophysiological roles. Recent studies using transgenic and knockout mice for several $\mathrm{sPLA}_{2}$ isoforms, in combination with lipidomics approaches, have revealed their distinct contributions to various biological events. Herein, we will describe several examples of $\mathrm{sPLA}_{2}$-mediated phospholipid metabolism in vivo, as revealed by integrated analysis of $\mathrm{sPLA}_{2}$ transgenic/knockout mice and lipid mass spectrometry. Knowledge obtained from this approach greatly contributes to expanding our understanding of the $\mathrm{SPLA}_{2}$ biology and pathophysiology.

Keywords: phospholipase $\mathrm{A}_{2}$; phospholipid; lipidomics; transgenic mouse; knockout mouse

Abbreviations: PLA 2 , phospholipase $\mathrm{A}_{2} ; \mathrm{sPLA}_{2}$, secreted PLA 2 ; $\mathrm{CPLA}_{2}$, cytosolic PLA ${ }_{i P L A}, \mathrm{Ca}^{2+}$-independent $\mathrm{PLA}_{2}$; Tg, transgenic; ARDS, acute respiratory distress syndrome; BALF, bronchoalveolar fluid; LPS, lipopolysaccharide; ESI-MS, electrospray ionization mass spectrometry; PC, phosphatidylcholine; LPC, lysophosphatidylcholine; PG, phosphatidylglycerol; PE, phosphatidylethanolamine; PS, phosphatidylserine; 
LDL, low-density lipoprotein; HDL, high-density lipoprotein; VLDL, very low-density lipoprotein; $\mathrm{ABC}$, ATP-binding cassette; $\mathrm{PGD}_{2}$, prostaglandin $\mathrm{D}_{2} ; \mathrm{PGE}_{2}$, prostaglandin $\mathrm{E}_{2}$; $\mathrm{LTB}_{4}$, leukotriene $\mathrm{B}_{4}$; PUFA, polyunsaturated fatty acid; DHA, docosahexaenoic acid; DPA, docosapentaenoic acid; LXR, liver X receptor; PPAR, peroxisome proliferatoractivated receptor; StAR, steroidogenic acute regulatory protein; DRG, dorsal root ganglion; COX, cyclooxygenase; LOX, lipoxygenase; CYP450, cytochrome P450; HPLC, high performance liquid chromatography; WT, wild-type.

\section{Introduction}

Phospholipase $\mathrm{A}_{2}\left(\mathrm{PLA}_{2}\right)$ hydrolyzes the $s n$-2 position of glycerophospholipids to yield fatty acids and lysophospholipids. In the view of signal transduction, the PLA 2 reaction has been considered to be of particular importance since arachidonic acid, one of the polyunsaturated fatty acids (PUFAs) released by $\mathrm{PLA}_{2}$, is metabolized to various lipid mediators such as prostaglandins and leukotrienes. In addition, lysophospholipids or its metabolites, such as lysophosphatidic acid and platelet-activating factor, also represent another class of lipid mediators. These lipid mediators exert numerous biological actions through their cognate $G$ protein-coupled receptors on target cells. PLA 2 has also been implicated in membrane glycerophospholipid remodeling, thereby contributing to cellular homeostasis.

Mammalian genomes encode more than $30 \mathrm{PLA}_{2} \mathrm{~S}$ or related enzymes, which are classified into several subgroups on the basis of their primary structures and functions. Critical contributions of the intracellular $\mathrm{PLA}_{2}$ families, namely cytosolic $\mathrm{PLA}_{2} \mathrm{~S}\left(\mathrm{cPLA}_{2} \mathrm{~S}\right)$ and $\mathrm{Ca}^{2+}$-independent $\mathrm{PLA}_{2} \mathrm{~S}\left(\mathrm{iPLA}_{2} \mathrm{~s}\right)$, to aracidnonic acid metabolism and membrane homeostasis, respectively, have been well established by numerous studies [1,2]. The secreted $\mathrm{PLA}_{2}\left(\mathrm{sPLA}_{2}\right)$ family represents structurally related, disulfide-rich, low molecular weight, lipolytic enzymes with a His-Asp catalytic dyad. $\mathrm{PLAA}_{2} \mathrm{~S}$ occur in a wide variety of vertebrate and invertebrate animals, plants, fungus, bacteria, and viruses, and $11 \mathrm{sPLA}_{2}$ isozymes (IB, IIA, IIC, IID, IIE, IIF, III, V, X, XIIA and XIIB) have been identified in mammals [2-4]. Of these, $\mathrm{sPLA}_{2} \mathrm{~s}$ belonging to the group I/II/V/X collection (conventional sPLA ${ }_{2} \mathrm{~s}$ ) are closely related, 14-19-kDa secreted enzymes with a highly conserved $\mathrm{Ca}^{2+}$-binding loop (XCGXGG) and a catalytic site (DXCCXXHD). In addition to these elements, there are six absolutely conserved disulfide bonds and up to two additional unique disulfide bonds, which contribute to the high degree of stability of these enzymes. Group III and group XII sPLA 2 s (atypical $\mathrm{sPLA}_{2} \mathrm{~s}$ ) share homology with the I/II/V/X collection of $\mathrm{SPLA}_{2} \mathrm{~s}$ only in the $\mathrm{Ca}^{2+}$-binding loop and catalytic site, thereby representing the group III and XII collections, respectively. sPLA ${ }_{2}$ enzymes hydrolyze the ester bond at the sn-2 position of glycerophospholipids with distinct selectivity toward $s n-2$ fatty acids and polar head groups in the presence of $\mathrm{mM}$ concentrations of $\mathrm{Ca}^{2+}$. Since individual $\mathrm{sPLA}_{2} \mathrm{~s}$ display distinct cellular/tissue distributions and substrate head group specificities, they may play non-redundant, isoform-specific roles in vivo.

Although many potential functions of $\mathrm{sPLA}_{2} \mathrm{~s}$ have been proposed on the basis of in vitro studies, the precise biological roles and relevant target membranes of these enzymes in vivo have remained elusive until recently. Several, if not all, $\mathrm{sPLA}_{2} \mathrm{~S}$ are capable of releasing arachidonic acid from 
cultured cell membranes when overexpressed or added exogenously at excess amounts in vitro [2-4]. However, it still remains controversial whether this function could indeed be operated by $\operatorname{sPLA}_{2} \mathrm{~S}$ in vivo. The reason why $\mathrm{sPLA}_{2} \mathrm{~S}$ are secreted is most probably because $\mathrm{sPLA}_{2} \mathrm{~S}$ participate in pathophysiology by regulating extracellular phospholipid metabolism, which include adjacent cell membranes (plasma membranes or microvesicles shed from cells), non-cellular lipid components such as lipoproteins and pulmonary surfactant, and foreign phospholipids such as microbe membranes and dietary lipids. The in vitro actions of individual $\mathrm{sPLA}_{2} \mathrm{~s}$ on various target membranes are summarized in Table 1. This target variation may explain the molecular evolution of a number of sPLA $\mathrm{S}_{2} \mathrm{~s}$ with distinct localizations and substrate specificities. Therefore, once some phenotypes appear in sPLA $_{2}$-knockout or -transgenic mice, this could be attributable to a combination of these varied actions rather than only by alterations in lipid mediator levels.

In the past few years, we have analyzed the phenotypes of transgenic or knockout mice for several $\mathrm{sPLA}_{2}$ isozymes, in combination with a lipid profiling technique by mass spectrometry. This integrated approach, together with studies using these mice by other research groups, has helped us understand the potential action of a given $\mathrm{SPLA}_{2}$ on particular target membranes and its impact on pathophysiology in vivo. In this article, we will give an overview of current analyses on transgenic or knockout mice for two particular conventional sPLA $2 \mathrm{~s}$, group $\mathrm{V}$ and $\mathrm{X}$, and an atypical $\mathrm{sPLA}_{2}$, group III. Also, we will give a brief summary of pathophysiological functions of other $\mathrm{SPLA}_{2} \mathrm{~S}$ that have been clarified to date.

Table 1. In vitro actions of $\mathrm{SLA}_{2} \mathrm{~S}$ on various membranes.

\begin{tabular}{|c|c|c|c|c|c|c|c|}
\hline$\underline{\mathbf{s L A A}_{2} \mathbf{S}}$ & & $\begin{array}{l}\text { resting cell } \\
\text { membrane }\end{array}$ & $\begin{array}{c}\text { activated cell } \\
\text { membrane }\end{array}$ & $\begin{array}{c}\text { lipoprotein } \\
\text { (PC) }\end{array}$ & $\begin{array}{c}\text { surfactant } \\
\text { (PC) }\end{array}$ & $\begin{array}{c}\text { Gram-positive } \\
\text { bacteria }\end{array}$ & $\begin{array}{c}\text { Gram-negative } \\
\text { bacteria }\end{array}$ \\
\hline \multirow[t]{7}{*}{ conventional $\mathrm{sPLA}_{2} \mathrm{~s}$} & IB & weak & moderate & weak & weak & none & none \\
\hline & IIA & none & moderate & weak & weak & very high & weak* \\
\hline & IID & none & weak & n.d. & weak & high & none \\
\hline & IIE & none & weak & n.d. & n.d. & moderate & none \\
\hline & IIF & moderate & moderate & moderate & n.d. & none & none \\
\hline & V & high & very high & very high & very high & high & none \\
\hline & $\mathrm{X}$ & very high & very high & very high & high & moderate & none \\
\hline \multirow[t]{2}{*}{ atypical sPLA ${ }_{2} \mathrm{~s}$} & III & moderate & moderate & high & n.d. & n.d. & none \\
\hline & XIIA & none & none & n.d. & n.d. & high & moderate \\
\hline
\end{tabular}

n.d.; not determined. $\mathrm{SPLA}_{2}$-IIC is not included since it is a pseudogene in human.

* sPLA $_{2}$-IIA kills Gram-negative bacteria only in the presence of bacterial permeability-increasing protein.

For details, please see refs $[30,31,41,47,55,79,85,94]$.

\section{Biological Functions of $\mathrm{SPLA}_{2} \mathrm{~S}$ in Vivo}

\subsection{Group V $s P L A_{2}\left(s P L A_{2}-V\right)$}

Among the conventional ${ }_{s P L A} \mathrm{~S}, \mathrm{sPLA}_{2}-\mathrm{V}$ has the simplest structure. It lacks group I- and II-specific disulfide bonds, group II-specific C-terminal extension, and group I- or X-specific $\mathrm{N}$-terminal propeptide [5]. However, $\mathrm{SPLA}_{2}-\mathrm{V}$ is evolutionally close to group II sPLA ${ }_{2} \mathrm{~S}$, since the 
Pla2g5 gene resides within the gene cluster for the group II subfamily of $\mathrm{sPLA}_{2} \mathrm{~s}$. sPLA $\mathrm{A}_{2} \mathrm{~V}$ is expressed at the highest level in the heart, followed by the lung. In the lung, sPLA $\mathrm{SL}_{2}-\mathrm{V}$ is expressed in the airway epithelium and alveolar macrophages, and its expression is markedly elevated in mice receiving models of asthma or acute respiratory distress syndrome (ARDS) [6]. Immunohistochemistry and in situ hybridization of sPLA $2-\mathrm{V}$ clearly indicate its location in the bronchial epithelium of patients with severe pneumonia [7].

To assess the biological functions of $\mathrm{SPLA}_{2}-\mathrm{V}$, we generated transgenic mice overexpressing this enzyme in the whole body (Pla2g5-Tg) [8]. We found that Pla2g5-Tg mice died in the neonatal period (within $8 \mathrm{~h}$ after birth) due to respiratory failure. The lungs of Pla2g5-Tg mice exhibited atelectasis with thickened alveolar walls and narrow air spaces, accompanied by infiltration of macrophages and only modest elevations in eicosanoid levels. This severe pulmonary defect in Pla2g5-Tg mice was attributable to marked reduction of the lung surfactant phospholipids, phosphatidylcholine (PC) (Figure 1a) and phosphatidylglycerol (PG) (Figure 1b), as demonstrated by ESI-MS (electrospray ionization mass spectrometry) analysis.

The principal function of lung surfactant, which is a mixture of phospholipids (90\%) and surfactant proteins $(10 \%)$, is to reduce the work of breathing by lowering alveolar surface tension during respiration. PC with saturated and monosaturated fatty acids (palmitic acid in particular) is predominant in surfactant phospholipids ( $~ 80 \%$ of total lipid) [9], and PG ( 10\% of total lipid) plays a role in phospholipid-protein interactions that maintain the alveolar surfactant layer, especially through interaction with the surfactant protein SP-B [10]. Since changes in the ratio of the surfactant components can dramatically alter the surface tension in small airways and alveoli, compromising airway patency, gas exchange and host defense, any surfactant abnormality can have severe pathological consequences in terms of lung function. Indeed, previous studies have indicated a role of $\mathrm{SPLA}_{2} \mathrm{~S}$ in inflammation-mediated surfactant malfunction through hydrolysis of surfactant phospholipids [11-18]. Aberrant hydrolysis of surfactant phospholipids leads to ARDS, which is a clinically and pathologically complex syndrome due to acute life-threatening lung injury involving an alteration of pulmonary surfactant, and numerous predisposing factors can be involved in the etiology, including pneumonia and sepsis [9]. Hydrolysis of surfactant phospholipids is an early pathological event of ARDS, and hydrolysis of as little as $10-15 \%$ of surfactant can cause this serious condition. Levels of SPLA $_{2}$ activity in bronchoalveolar fluid (BALF) of patients with ARDS are often positively correlated with disease severity [11-14], and chemical sPLA 2 inhibitors that block classical sPLA $\mathrm{S}_{2}$ protect animals against experimental ARDS or related lung injury [15]. Given that the expression of $\mathrm{sPLA}_{2}-\mathrm{V}$ is greatly elevated in human lungs with severe inflammation [7] and in cultured human bronchial epithelial cells stimulated with pro-inflammatory cytokines (Figure 1c), that sPLA $2-\mathrm{V}$ can efficiently hydrolyze lung surfactant phospholipids in vitro [16,18], and that the neonatal death of Pla2g5-Tg mice is in many aspects similar to that observed in mutant mice manipulated for a panel of genes that have been implicated in surfactant homeostasis [19,20], sPLA $_{2}-\mathrm{V}$ may contribute to ongoing surfactant hydrolysis often observed in the lungs of patients with ARDS (Figure 1d). 
Figure 1. Pla2g5-Tg mice display fatal respiratory failure due to lung surfactant destruction. (a and b) ESI-MS of surfactant PC (a) and PG (b) from Pla2g5-Tg mice (right) and WT mice (left); Molecular peaks shown in red, such as PC32:0 (16:0-16:0) and PC32:1 (16:0-16:1) (a) as well as PG32:0 (16:0-16:0), PG34:1 (16:0-18:1), PG36:4 (16:0-20:4) and PG38:6 (16:0-22:6); (b) were dramatically reduced in Pla2g5-Tg mice compared with WT mice. IS, internal standard; (c) RT-PCR of $\mathrm{sPLA}_{2}-\mathrm{V}$ mRNA in cultured human bronchial epithelial cells with or without stimulation for $12 \mathrm{~h}$ with pro-inflammatory cytokines. sPLA $_{2}-\mathrm{V}$ was induced by IL-1 $\beta$ or TNF $\alpha$ but not by IFN $\gamma$; (d) A schematic model of the role of $\mathrm{sPLA}_{2}-\mathrm{V}$ in lung surfactant hydrolysis. $\mathrm{SPLA}_{2}-\mathrm{V}$ is secreted from bronchial epithelial cells and alveolar macrophages stimulated with pro-inflammatory cytokines, and aberrant hydrolysis of surfactant PC and PG by $\mathrm{SPLA}_{2}-\mathrm{V}$ leads to airway injury. For details, see [8].

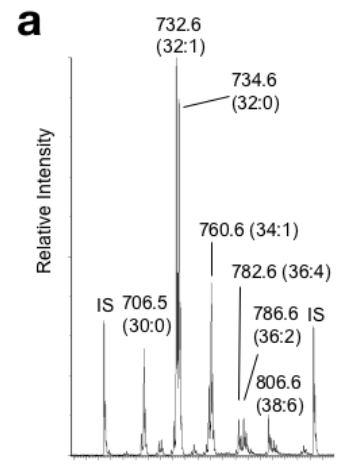

b

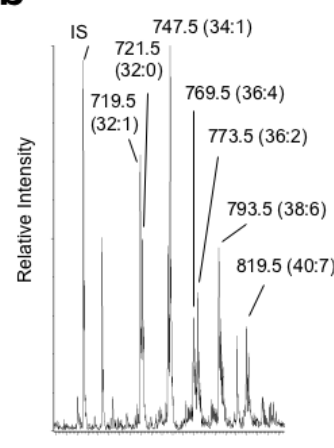

WT

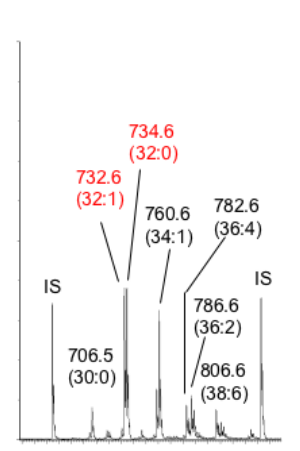

Pla2g5-Tg

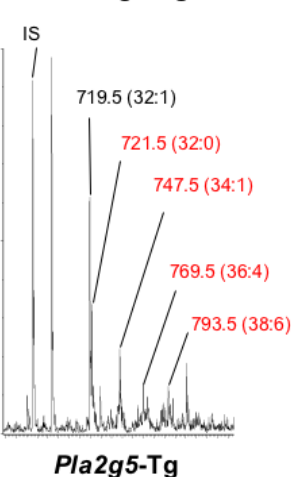

Pla2g5-Tg
C

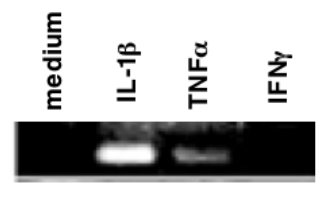

d

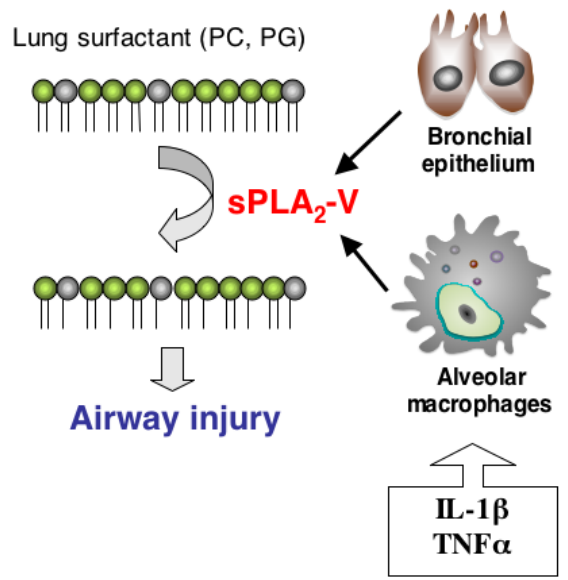

Following our study using Pla2g5-Tg mice as shown above, three studies using mice null for $\mathrm{SPLA}_{2}-\mathrm{V}\left(\mathrm{Pla}_{2} \mathrm{~g} 5^{-/-}\right)$by other groups have delineated the crucial contribution of this $\mathrm{SPLA}_{2}$ isoform to mouse airway disease models [6,21,22]. Thus, the allergen (ovalbumin or house dust mite)-induced, Th2-dependent asthmatic models, as well as the LPS-induced ARDS model, were significantly reduced in $P l a 2 g 5^{-/-}$mice compared with replicate $P l a 2 g 5^{+/+}$mice $[6,21]$. In the asthmatic models, the action of $\mathrm{sPLA}_{2}-\mathrm{V}$ occurs in two regulatory steps; one at the step of antigen uptake and processing by dendritic cells leading to the initiation of the Th2 response, and the other at the step of airway-resident cells which may contribute to the propagation of airway inflammation [22]. The airway-resident cell-dependent pathway requires catalytic activity of $\mathrm{SPLA}_{2}-\mathrm{V}$, since aerosolized intake of native, but not mutant, $\mathrm{sPLA}_{2}-\mathrm{V}$ caused a dose-related increase of airway resistance, persistent airway narrowing, and leukocyte migration, and since intratracheal application of a neutralizing antibody against $\mathrm{SPLA}_{2}-\mathrm{V}$ ameliorated the asthmatic response [6]. However, eicosanoid levels in BALF were 
unchanged in this model, suggesting that the airway action of $\mathrm{SPLA}_{2}-\mathrm{V}$ does not profoundly depend on lipid mediators. Although the molecular mechanism underlying the airway-resident cell-dependent pathway has not yet been clarified, we speculate that the protection from disease-associated surfactant hydrolysis by the absence of $\mathrm{SPLA}_{2}-\mathrm{V}$ may be a likely explanation for this event. Thus, blockade of endogenous $\mathrm{SPLA}_{2}-\mathrm{V}$ could provide a potential new therapeutic approach for treating diverse phenotypes of human asthma.

Studies using Pla2 $\mathrm{g}^{-/-}$mice have also revealed unique functions of $\mathrm{SPLA}_{2}-\mathrm{V}$ in inflammation, host defense, and atherosclerosis. Pla $2 g 5^{-/-}$mice displayed reduced zymosan-induced peritonitis since peritoneal macrophages produced less eicosanoids [23], were protected from Candida albicans infection since phagocytic killing of the fungi by macrophage was reduced [24,25], and were more sensitive to inflammatory arthritis since phagocytosis of the pro-inflammatory immune-complex by macrophages was reduced in the joints [26]. SPLA $_{2}-\mathrm{V}$ can also potently hydrolyze phospholipids in low-density (LDL) and high-density (HDL) lipoprotein particles, and LDL receptor-deficient mice transplanted with Pla2g $5^{-/-}$bone marrow cells are partially protected from atherosclerosis development [27]. Furthermore, a recent single nucleotide polymorphism analysis has revealed an association of the human $\mathrm{sPLA}_{2}-\mathrm{V}$ gene haplotype with plasma LDL levels in patients with type 2 diabetes [28], suggesting its metabolic role.

\subsection{Group $X{ }_{s P A_{2}}\left(s P L A_{2}-X\right)$}

Structurally, $\mathrm{sPLA}_{2}-\mathrm{X}$ has both the group I- and II-specific properties. Unlike $\mathrm{SPLA}_{2}-\mathrm{V}$, which is constitutively active once synthesized, $\mathrm{sPLA}_{2}-\mathrm{X}$ is synthesized as an inactive zymogen and converted to an active enzyme by proteolytic removal of the $\mathrm{N}$-terminal propeptide [29]. Amongst the sPLA 2 members, $\mathrm{sPLA}_{2}-\mathrm{X}$ shows the highest affinity for PC and thereby for the PC-rich outer leaflet in the plasma membrane of mammalian cells [30,31]. Accordingly, supplementation or forcible transfection of exogenous $\mathrm{SPLA}_{2}-\mathrm{X}$ results in increased release of arachidonic acid and its oxygenated metabolites in many cell types. However, these results should be carefully interpreted, because unlike cPLA ${ }_{2} \alpha$, which is ubiquitously expressed and is a central player of arachidonic acid release [1], the expression of $\mathrm{SPLA}_{2}-\mathrm{X}$ is tissue- or cell-specific. In fact, $\mathrm{sPLA}_{2}-\mathrm{X}$ is constitutively expressed at high levels in the genital and digestive organs, where they play roles in sperm activation and gastrointestinal phospholipid digestion, respectively, independently of lipid mediator production [32,33].

In the lung, $\mathrm{sPLA}_{2}-\mathrm{X}$ is focally expressed in airway epithelial cells, and its expression is elevated in the epithelium as well as in alveolar macrophages following asthmatic challenge in both mice and humans $[34,35]$. The contribution of $\mathrm{sPLA}_{2} \mathrm{X}$ to airway inflammation was confirmed by a study using mice lacking this enzyme (Pla2g10 $10^{--}$), in which the ovalbumin-induced, Th2-dependent asthmatic responses in the airway, including infiltrations of $\mathrm{CD}^{+}$and $\mathrm{CD}^{+} \mathrm{T}$ cells and eosinophils, mucus secretion, elevation of Th2 cytokines, and production of pro-asthmatic lipid mediators such as cysteinyl leukotrienes and prostaglandin $\mathrm{D}_{2}\left(\mathrm{PGD}_{2}\right)$, were markedly reduced [34]. Taken together with the evidence from $\mathrm{Pla}_{2} \mathrm{~g}^{-/-}$mice (see above), it has become obvious that the two particular $\mathrm{SPLA}_{2} \mathrm{~S}$, $\mathrm{SPLA}_{2}-\mathrm{V}$ and $-\mathrm{X}$, participate in the asthma pathology. In addition, Pla $2 \mathrm{~g} 10^{-/-}$mice are protected from neutrophil-induced myocardial damage following ischemia-reperfusion, where sPLA $\mathrm{A}_{2}-\mathrm{X}$ is involved in the production of leukotriene $\mathrm{B}_{4}\left(\mathrm{LTB}_{4}\right)$ by neutrophils [36]. 
In order to address the in vivo action of $\mathrm{sPLA}_{2}-\mathrm{X}$, we produced transgenic mice overexpressing this enzyme in the whole body (Pla2g10-Tg) [8]. Unexpectedly, in contrast to Pla2g5-Tg neonates that exhibited fatal respiratory failure (see above), systemic Pla2g10-Tg mice displayed no apparent abnormality of the respiratory tract with normal alveolar architecture and surfactant composition [8], despite the fact that $\mathrm{SPLA}_{2}-\mathrm{X}$ can potently hydrolyze surfactant $\mathrm{PC}$ in vitro [18]. This surprising result turned out to be because $\mathrm{sPA}_{2}-\mathrm{X}$ protein existed as an inactive zymogen in most tissues. The active form of $\mathrm{sPLA}_{2} \mathrm{X}$ was produced at inflamed sites in Pla2g10-Tg mice [8]. These results suggest that $\mathrm{sPLA}_{2}-\mathrm{X}$ mostly exists as an inactive zymogen under physiological conditions and that its proteolytic activation occurs during inflammation. In contrast, macrophage-specific Pla2g10-Tg mice developed severe lung inflammation which led to early death by 2 3-weeks of age [37]. Although the discrepancy between systemic and macrophage-specific Pla2g10-Tg mice is unclear, sPLA 2 X expressed in alveolar macrophages might be efficiently converted by proteolytic processing to an active form.

Although systemic Pla2g10-Tg mice did not have any alveolar injury, we found a remarkable phenotype in these mice before weaning: they developed alopecia [38]. Although pelage hairs of Pla2g10-Tg mice initially grew, complete but transient hair loss was observed at 3-4 weeks of age, a period corresponding to the late stage of the initial hair cycle (Figure 2a). Proteolytic activation of $\mathrm{sPLA}_{2}-\mathrm{X}$ in Pla2g10-Tg skin temporally preceded hair loss. Histological analyses of the alopecic Pla2g10-Tg skin revealed hair follicle distortion, hyperkeratosis and sebaceous gland hyperplasia (Figure 2b), which were accompanied by increased expression of genes related to terminal differentiation of epidermis and reduced expression of genes related to hair development. ESI-MS analysis of Pla2g10-Tg skin revealed that $\mathrm{SPLA}_{2}-\mathrm{X}$ hydrolyzed phosphatidylethanolamine (PE), but not PC, molecular species to yield PUFAs (Figure 2c), which were further converted to some if not all eicosanoids. A schematic model for the action of $\mathrm{SPLA}_{2}-\mathrm{X}$ in Pla2g10-Tg skin is illustrated in Figure 2d. These results, together with the finding that endogenous $\mathrm{sPLA}_{2} \mathrm{X}$ shows a hair cycle-dependent periodic expression in the outer root sheath of hair follicles in mouse skin (Figure 2e) [38], suggest a potential functional link between $\mathrm{SPLA}_{2} \mathrm{X}$ and skin biology, and may provide a molecular explanation for the skin abnormality induced by aberrant expression of other SPLA $_{2}$ S such as SPLA 2 -IIA, whose transgenic mice also developed alopecia [39]. Importantly, in Pla2g10 ${ }^{-/}$mice, hair growth in the anagen phase was significantly delayed, and this was caused by growth retardation of the outer root sheath in hair follicles [40]. Thus, $\mathrm{sPLA}_{2} \mathrm{X}$ intrinsically functions in the hair quality control.

The ability of $\mathrm{sPLA}_{2}-\mathrm{X}$ to potently hydrolyze phospholipids in LDL and HDL in vitro has led to the hypothesis that, as in the case of $\mathrm{SPLA}_{2}-\mathrm{V}$ (see above), $\mathrm{sPLA}_{2}-\mathrm{X}$ may also participate in atherosclerosis. Indeed, sPLA 2 -X-hydrolyzed LDL particles promote foam cell formation from mouse peritoneal macrophages [41]. These in vitro observations may be relevant to cardiovascular pathology, since Pla2g $10^{-/-}$mice are protected from angiotensin-II-induced aortic aneurysm and atherosclerosis [42]. $\mathrm{SPLA}_{2}$-X-released PUFAs negatively regulates liver X receptor (LXR), and accordingly, deficiency of $\mathrm{sPLA}_{2}-\mathrm{X}$ results in augmented LXR activation leading to increased expression of LXR-target genes. Thus, in Pla $2 \mathrm{~g} 10^{-/-}$mice, elevated expression of the ATB-binding cassette (ABC) transporters ABCA1 and ABCG1 led to increased cholesterol efflux by macrophages [43], that of the steroidogenesis acute regulatory protein StAR resulted in increased corticosterone production by adrenal cells [44], and that of PPAR $\gamma$ (peroxisome proliferator-activated receptor $\gamma$ ) facilitated adipogenesis and adiposity [45]. 
On the contrary, Pla2 $\mathrm{g} 10^{-/}$mice maintained on a chow diet over one year gradually lost body weight, most likely because dietary phospholipid digestion and thereby lipid absorption in the gastrointestinal tract was perturbed [38]. Collectively, these observations have highlighted a novel role of sPLA $\mathrm{A}_{2} \mathrm{X}$ in the regulation of metabolic states.

Figure 2. Pla2g10-Tg mice display alopecia during the postnatal hair cycle. (a) Pla2g10-Tg mice displayed temporary alopecia during 2-3 wk after birth, a period of the postnatal hair cycle; (b) Histology of 3-wk-old Pla2g10-Tg mice, in comparison with that of WT mice, revealed hair follicle distortion as well as epidermal hyperplasia, sebaceous gland enlargement, and cyst formation; (c) ESI-MS of skin phospholipids indicated that PE molecular species with PUFA (arachidonic acid (C20:4) and docosahexaenoic acid (C22:6)), but not PC, was markedly decreased in Pla2g10-Tg mice compared with WT mice; (d) A schematic model of the $\mathrm{sPLA}_{2}-\mathrm{X}$ action in the skin. $\mathrm{sPLA}_{2}-\mathrm{X}$ is converted by certain skin proteases to its active form, which then hydrolyzes PE in skin membranes to liberate PUFA that is further metabolized to skin-acting eicosanoids; (e) Endogenous $\mathrm{SPLA}_{2}-\mathrm{X}$ is localized in the ORS of hair follicles (shown in red). ORS, outer root sheath; IRS, inner root sheath. For details, see [38].

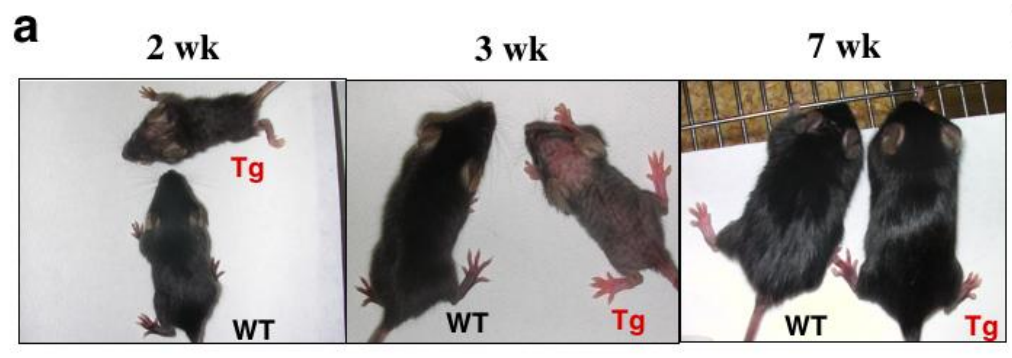

b

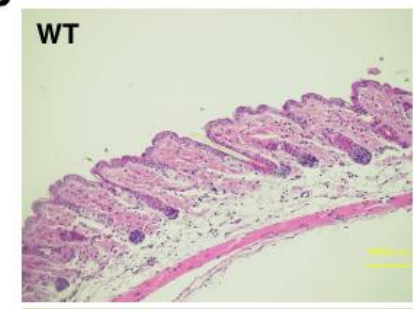

C
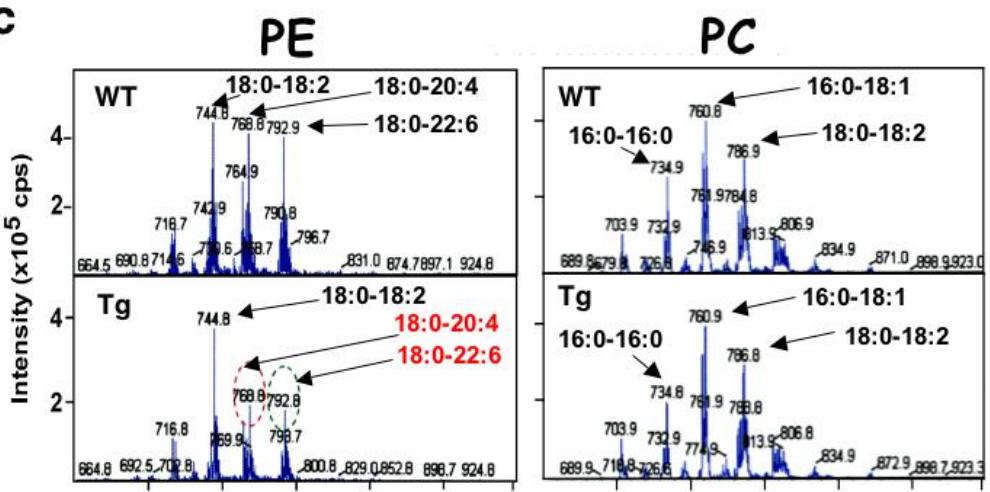

d
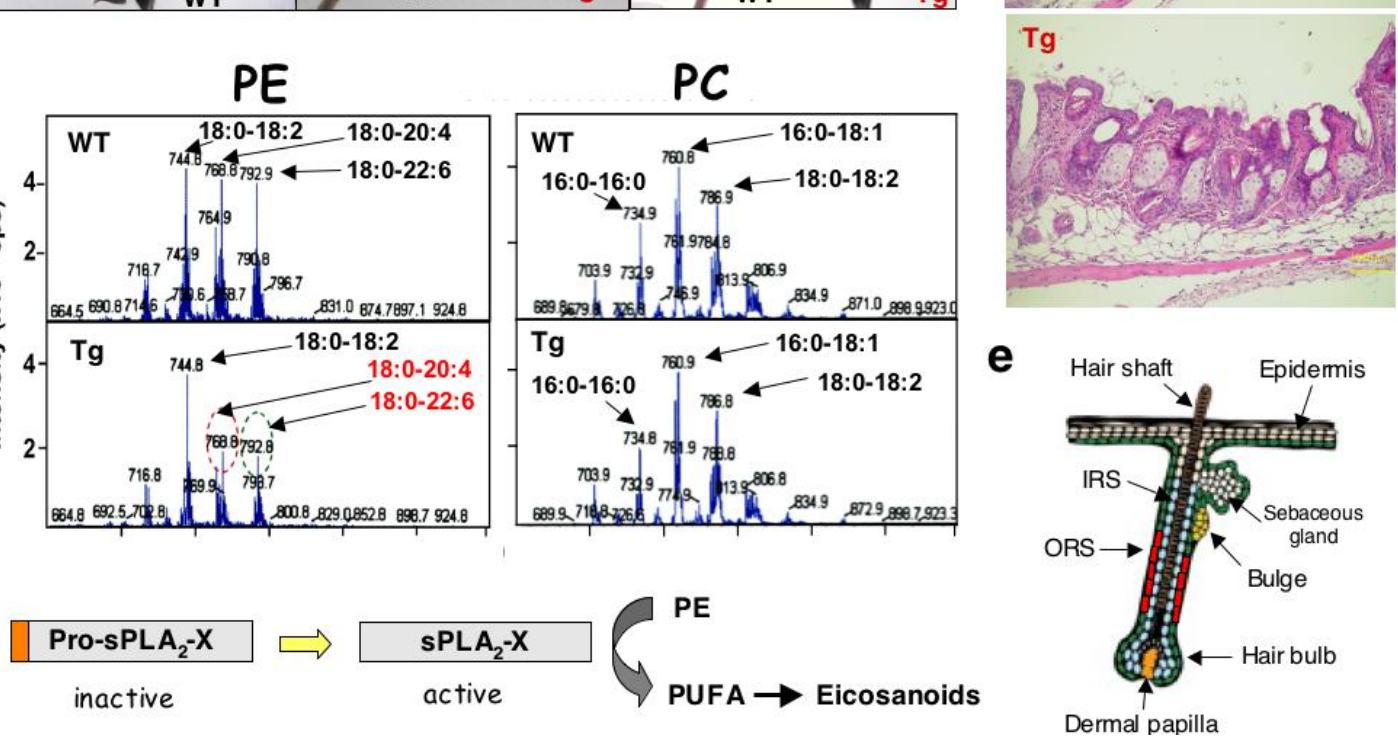

Finally, sPLA $\mathrm{s}_{2}-\mathrm{X}$ is abundantly expressed in testicular spermatigenic cells and is released from the acrosome of capacitative (activated) sperm. Pla2 $10^{-/}$spermatozoa displayed reduced acrosome reaction and thereby reduced fertility, and this defect could be restored by LPC, a potential sPLA $_{2}-\mathrm{X}$-generated lipid product $[32,38]$. $\mathrm{sPLA}_{2}-\mathrm{X}$ is also expressed in peripheral neurons such as dorsal ganglion (DRG) neurons, and DRG from Pla2g10 $10^{-/}$mice showed reduced, whereas that from Pla2g10-Tg mice showed increased, ex vivo neuritogenesis [38]. Probably because of the altered 
neuritogenesis, pain nociception in the acetic acid writhing test was partially ameliorated in Pla2g10 $10^{-/}$mice, whereas it was augmented in Pla2g10-Tg mice, compared with that in littermate control mice [38].

\subsection{Group III $s P L A_{2}\left(s P L A_{2}-I I I\right)$}

sPLA $_{2}$-III is the only enzyme belonging to the group III collection. It is an unusually large protein $(55 \mathrm{kDa})$ among the $\mathrm{sPLA}_{2}$ family and consists of three domains, in which a central $\mathrm{sPLA}_{2}$ domain displaying all the features of group III bee venom $\mathrm{SPLA}_{2}$, including 10 cysteines and the key residues of the $\mathrm{Ca}^{2+}$ loop and catalytic site, is flanked by large and unique $\mathrm{N}$ - and C-terminal region [46]. sPLA $_{2}$-III is processed to a sPLA 2 domain-only form (devoid of the $\mathrm{N}$ - and C-terminal domains), which is sufficient for its catalytic function $[47,48]$. sPLA 2 -III undergoes N-glycosylation and can hydrolyze PC and PE equally and augment arachidonate release from cell membranes more efficiently than $\mathrm{sPLA}_{2}$-IIA, and less efficiently than $\mathrm{SPLA}_{2}-\mathrm{X}$ and $\mathrm{sPLA}_{2}-\mathrm{V}$. $\mathrm{sPLA}_{2}-\mathrm{III}$ is immunohistochemically detected in the vascular endothelium of various tissues, peripheral and central nervous systems, male

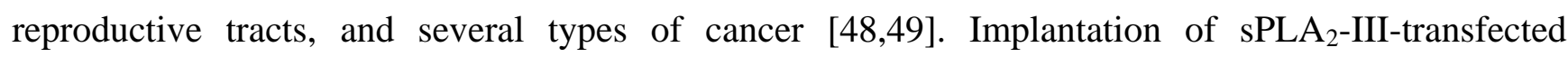
colorectal adenocarcinoma cells into nude mice promotes the growth of tumor xenografts [48]. Expression profiling of the full set of $\mathrm{sPLA}_{2} \mathrm{~s}$ in human colon suggests that $\mathrm{sPLA}_{2}$-III might be a good candidate as a novel biomarker for colon cancers [50]. In the central nervous system, Pla2g3 mRNA is localized in DRG neurons in mice, and overexpression of human $\mathrm{SPLA}_{2}$-III in cultured neuronal cells facilitates neurite outgrowth and survival in correlation with the production of LPC, whereas knockdown of endogenous sPLA 2 -III by siRNA partially suppresses these processes [49].

To address the potential in vivo action of $\mathrm{sPLA}_{2}$-III, we produced transgenic mice overexpressing this enzyme in the whole body (Pla2g3-Tg). Unlike Pla2g5-Tg mice, which die shortly after birth due to a lung disorder resulting from aberrant hydrolysis of the lung surfactant phospholipids (see above), Pla2g3-Tg mice showed no respiratory disorder, and lung surfactant phospholipids did not show appreciable difference between control and Pla2g3-Tg mice [51]. Furthermore, although Pla2g10-Tg mice show alopecia (see above), Pla2g3-Tg mice had normal pelage hairs up to nine months of age. Later on, however, Pla2g3-Tg mice spontaneously developed inflammation such as dermatitis, lymphocytic sialadenitis and splenomegaly [51]. The dermatitis was accompanied by hyperkeratosis, acanthosis, parakeratosis, erosion, ulcer, neutrophil infiltration, and increased production of proinflammatory cytokines, chemokines and prostaglandin $\mathrm{E}_{2}\left(\mathrm{PGE}_{2}\right)$. It is thus likely that overexpression of $\mathrm{sPLA}_{2}$-III facilitates the production of pro-inflammatory lipid mediators in the whole body, leading to systemic inflammation.

To look for potential substrates for sPLA 2 -III in Pla2g3-Tg mice, lipids extracted from splenocytes of aged Pla2g3-Tg and littermate control mice were subjected to ESI-MS analysis. Several PC molecular species were detected in splenocytes of wild-type (WT) mice, and their composition did not differ appreciably from those of Pla2g3-Tg mice (Figure 3a, Upper). However, a notable difference

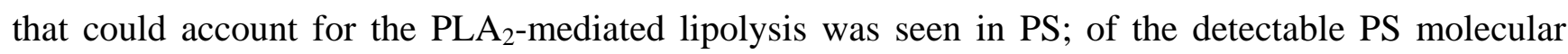
species, PS with C18:0-18:1 $(\mathrm{m} / \mathrm{z}=790.6)$ were $~ 50 \%$ less in Pla2g3-Tg mice than in control mice (Figure 3a, Lower). These results suggest that, in splenocyte membranes, PS with C18:0-18:1 may represent a major target substrate of sPLA $_{2}$-III. Since PS is mainly present in the inner leaflet of the 
plasma membrane of live cells and exposed on apoptotic cell surfaces [52,53], extracellular sPLA 2 -III might preferentially hydrolyze PS with C18:0-18:1 on apoptotic cells and thereby modulate the life-span of inflammatory cells. In support of this idea, susceptibility of cell membranes to sPLA $\mathrm{S}_{2}$ increases in apoptotic cells [54].

As in the case of $\mathrm{sPLA}_{2}-\mathrm{V}$ and $-\mathrm{X}, \mathrm{sPLA}_{2}$-III can potently hydrolyze phospholipids in plasma lipoprtein particles [55]. Indeed, the decreased level of plasma lipoproteins, HDL in particular, was obvious in Pla2g3-Tg mice in comparison with WT mice (Figure 3b), suggesting HDL hydrolysis by overexpressed $\mathrm{sPLA}_{2}$-III. LDL treated with $\mathrm{SPLA}_{2}$-III in vitro was pro-atherogenic, promoting foam cell formation from macrophages. When Pla2g3-Tg mice that had been crossed with ApoE ${ }^{-/-}$mice $\left(P l a 2 g 3^{t g} / A_{p o E^{-/}}\right)$were fed a high-cholesterol diet, lipid accumulation in the aortic walls was markedly increased as compared with replicate $\mathrm{ApoE}^{-/}$mice (Figure $3 \mathrm{c}$ ). Immunohistochemistry and in situ hybridization revealed the presence of $\mathrm{SPLA}_{2}$-III in human atherosclerotic plaques, particularly in macrophages and smooth muscle cells $[55,56]$. These results suggest that sPLA $_{2}$-III may have a role in acceleration of atherosclerosis development [55].

Figure 3. Pla2g3-Tg mice display systemic inflammatory and atherosclerotic phenotypes. (a) ESI-MS of PC and PS in splenocytes from Pla2g3-Tg (III-Tg) and wild-type (WT) mice. Major peaks are indicated by arrows. Peaks altered in III-Tg mice relative to WT mice are shown in red. SM, sphingomyelin; (b) HPLC profile of plasma lipoproteins in III-Tg and WT mice; (c) Increased atherosclerosis in III-Tg mice on the ApoE ${ }^{-/-}$ background (male, 24-wk-old). Atheroslcerotic lesions were visualized by oil red O staining. Areas positive for the staining were quantified. For details, see [51,55].

a
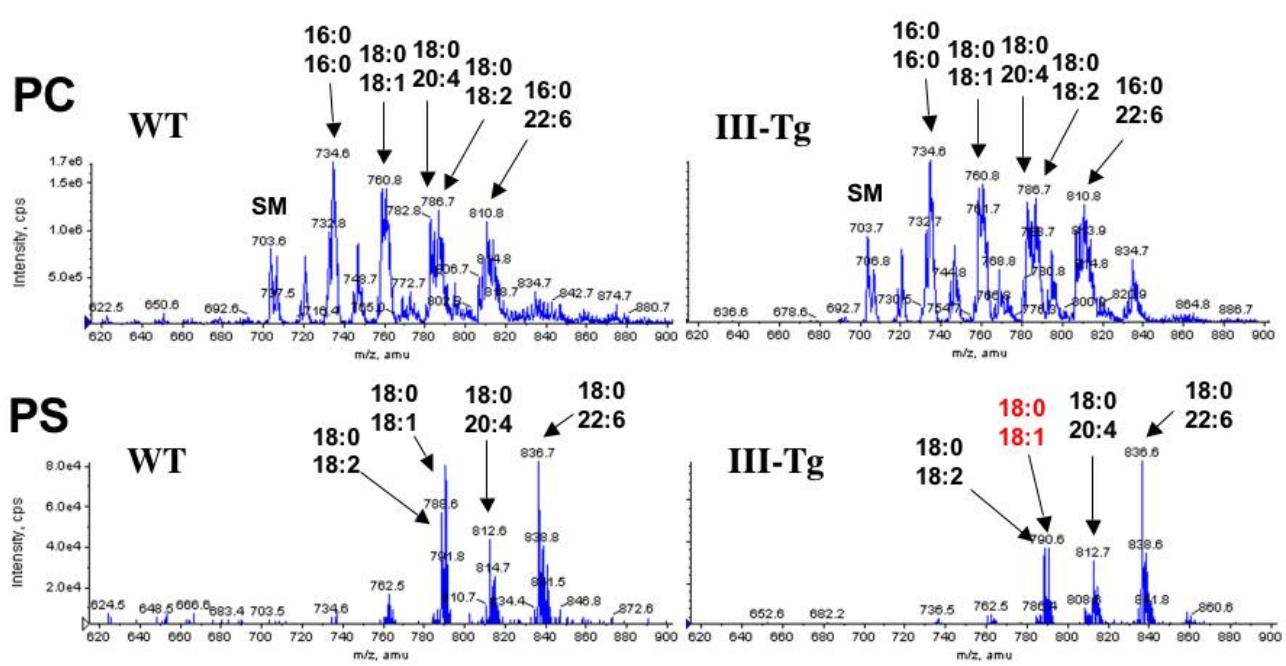

b

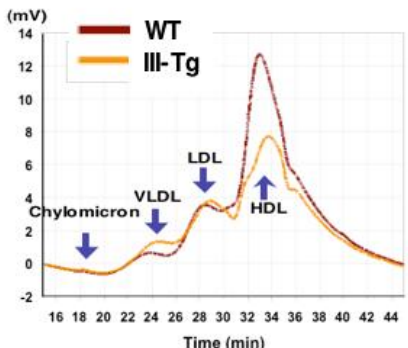

C

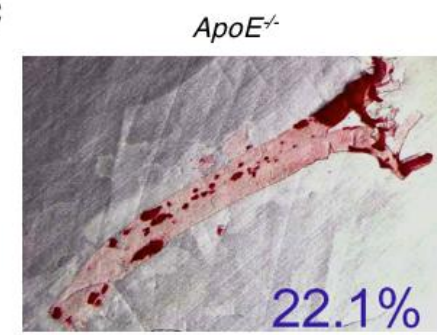

III-Tg $X A p o E^{-/}$

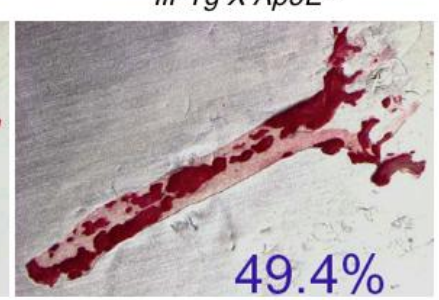


Figure 4. $\mathrm{Pla} 2 \mathrm{~g}^{-/-}$mice have multiple defects in epididymal sperm maturation. (a) Altered eicosanoid levels in Pla2 $\mathrm{g} 3^{-/-}$mice. The levels of individual eicosanoids in the epididymis were determined by LC-ESI-MS/MS. SPLA 2 -III is selectively coupled with 12/15-LOX and CYP450 pathways; (b) Unusual accumulation of PC molecular species in the epididymal fluids from $\mathrm{Pla} 2 \mathrm{~g} 3^{-/-}$mice relative to $\mathrm{Pla} 2 \mathrm{~g} 3^{+/+}$mice, as assessed by ESI-MS; (c) The roles of $\mathrm{sPLA}_{2}$-III in epididymal sperm maturation are summarized. For details, see [57].

a

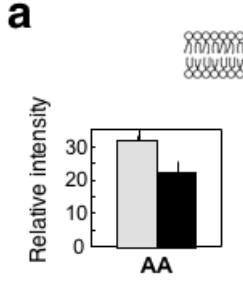

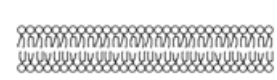

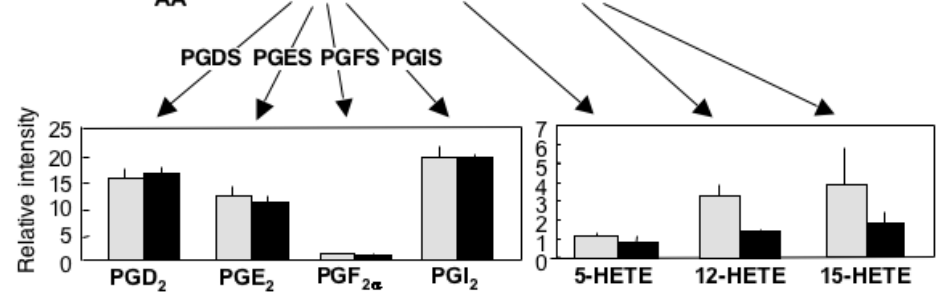

b

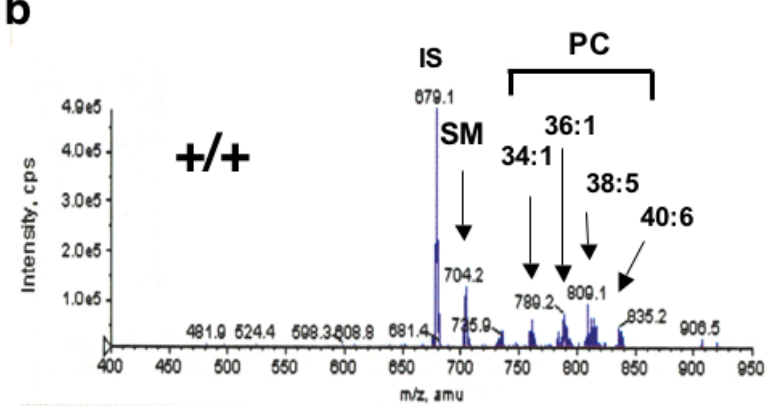

C
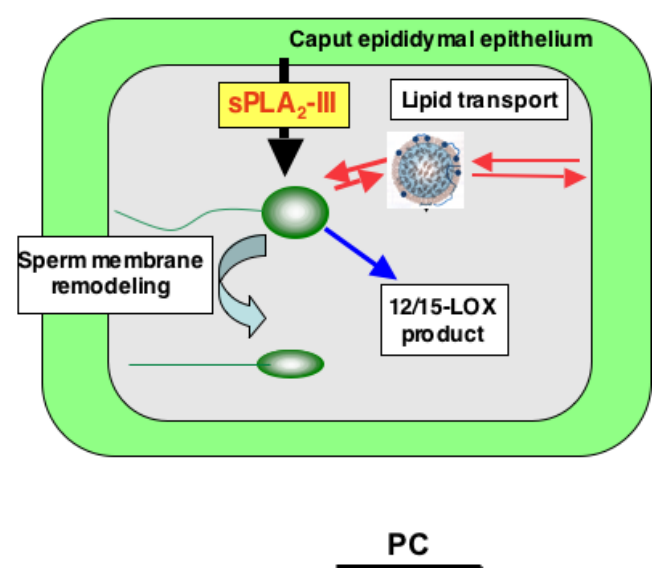

SM

PC

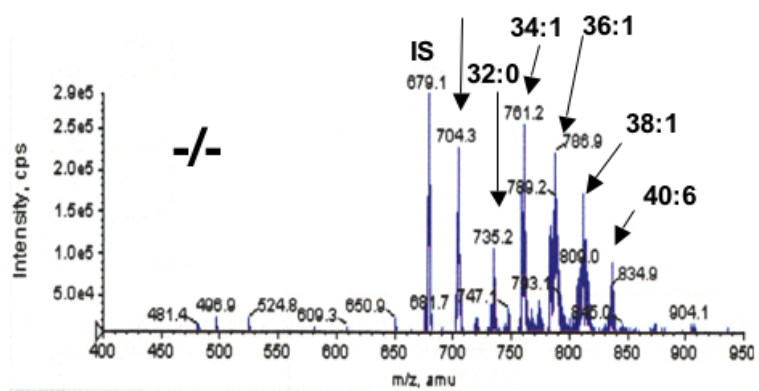

sPLA $_{2}$-III is expressed in the testis and epididymis, and in the latter tissue the mature form of $\mathrm{SPLA}_{2}$-III is secreted from the proximal epididymal epithelium into the lumen [57]. We have recently succeeded in generating Pla $2 g 3^{-/-}$mice and found that they displayed male infertility [57]. Although testicular spermatogenesis in Pla $2 \mathrm{~g}^{-/-}$mice was grossly normal, spermatozoa from the cauda (tail) epididymidis displayed hypomotility, and their ability to fertilize intact eggs was markedly impaired. Epididymal spermatozoa in Pla $23^{3^{-/}}$mice had aberrant acrosomal structures and flagella with abnormal axonemes. These results revealed an unexplored role of this atypical $\mathrm{SPLA}_{2}$ in epididymal lipid homeostasis, whose perturbation led to sperm dysfunction.

After the complex differentiation process of male germ cells, spermatozoa exit the seminiferous tubules of the testis through the efferent ducts toward the epididymis. During their transit from the caput (head) to the cauda (tail) epididymidis, sperm cells undergo significant morphological and biochemical modifications, which lead to acquisition of their forward motility and ability to recognize and fertilize oocytes [58]. Unique to mammalian sperm cells is the abundance of phospholipid species with C22-PUFAs, particularly docosahexaenoic acid (DHA) and docosapentaenoic acid (DPA), whose proportion in membrane phospholipids appears to correlate with sperm maturity, motility and 
fertility [59-62]. The percentage of DHA relative to total fatty acids is correlated with the normal morphology of sperm cells [61], and sperm from subfertile men with low sperm motility or counts contain a percentage of DHA lower than that from normal men [63]. Sperm maturation involves the remodeling of membrane phospholipids toward the acquisition of motility and fertility during sperm migration through the epididymis. Indeed, the increase in C22-PUFAs such as DHA and DPA and the reciprocal decrease in arachidonic acid (C20:4) favor an increase in the unsaturation degree of fatty acids in mouse sperm membrane during epididymal transit [59], which could consequently contribute to increasing the mouse sperm membranous fluidity [64,65]. Interestingly, ESI-MS analysis of sperm membrane phospholipids revealed that, during epididymal transit, PC in WT sperm underwent a dramatic shift in its acyl groups from oleic, linoleic and arachidonic acids to DPA and DHA, whereas this membrane lipid remodeling was compromised in Pla $23^{-/-}$sperm [57]. Accordingly, cauda epididymal spermatozoa in Pla $2 g 3^{-/-}$mice had PC species containing more oleate and less DHA/DPA than did those in Pla2g $3^{+/+}$mice, a finding that appears to be consistent with the aforementioned notion that sperm with higher DHA percentages have better motility and fertility. Thus, sPLA 2 -III may participate in the hydrolysis of PC with oleic, linoleic and arachidonic acids in the sperm membrane during epididymal transit and that this event may be followed by reacylation of LPC, a PLA 2 reaction product, with DHA and DPA, leading to an increase of PC with DPA/DHA in mature spermatozoa. In the Pla2g $3^{--}$epididymis, impairment of the deacylation step may eventually perturb the subsequent reconstitution of DPA/DHA in the sperm membrane, culminating in the asthenozoospermia phenotype.

We also found a notable change in the ESI-MS/MS profile of lipid mediators in the epididymis of $\mathrm{Pla}_{\mathrm{g}} 3^{-/-}$mice [57]. Thus, arachidonate/linoleate metabolites of the 12/15-lipoxygenase (LOX) and cytochrome P450 (CYP450) pathways, but not those of the cyclooxygenase (COX) and 5-LOX pathways, were substantially reduced in the epididymis of $P \operatorname{la} 2 g 3^{-/-}$mice compared with that of Pla $2 \mathrm{~g}^{+/+}$mice (Figure 4a). Although the role of 12/15-LOX or CYP450 metabolites in male fertility has not yet been fully established, expression of 12/15-LOX in spermatogenic cells has led to the suggestion that it may participate in sperm maturation [62]. In this context, the possibility that certain 12/15-LOX- or CYP450-derived lipid mediator(s) may be at least partly responsible for the regulation of sperm maturation by sPLA 2 -III should be taken into account.

Additionally, sPLA 2 -III may also affect lipid transport between sperm and epididymal epithelial cells. Several lipoprotein components are secreted by epididymal epithelial cells [67] and associate with and dissociate from sperm membranes scheduled for endocytosis by epididymal principal cells [68]. Male fertility can be impaired to various degrees by inactivation of the genes involved in lipoprotein metabolism [69-71]. In fact, membrane transport by epididymosomes, a particular lipoprotein membrane particle emitted from caput epididymal principal cells into the lumen, is fundamental for the process of sperm cell maturation in the epididymis $[59,72]$. Our speculation that sPLA $_{2}$-III may also affect this epididymal lipid transport is supported by the finding that, as assessed by ESI-MS, the epididymal fluid from Pla $23^{-/}$mice contained PC more abundantly than that from $P l a 2 g 3^{+/+}$mice (Figure $4 \mathrm{~b}$ ). Taken together, we conclude that $\mathrm{SPLA}_{2}$-III may regulate epididymal sperm maturation through (i) regulation of phospholipid remodeling in sperm membranes, (ii) production of 12/15-LOX and CYP450 metabolites, and (iii) modification of lipid transport between sperm and epididymal epithelial cells (Figure 4c). 


\subsection{Other $\mathrm{PLA}_{2}$ s: Classical and Novel Enzymes}

Group IB pancreatic $\mathrm{sPLA}_{2}\left(\mathrm{sPLA}_{2}-\mathrm{IB}\right)$ is synthesized in the pancreatic acinar cells, and after secretion into the pancreatic juice, an $\mathrm{N}$-terminal heptapeptide of the inactive zymogen is cleaved by trypsin to yield an active enzyme in the duodenum [74]. The main role of sPLA $A_{2}$ IB is digestion of dietary and biliary phospholipids. Thus, perturbation of this process by gene disruption $\left(\right.$ Pla $\left.2 g 1 b^{--}\right)$or pharmacological inhibition of $\mathrm{SPLA}_{2}$-IB led to protection from diet-induced obesity and insulin resistance due to decreased lipid digestion and absorption in the gut [75,76]. In agreement, the $P L A 2 G 1 B$ gene resides within a locus for obesity susceptibility in humans [77].

Group IIA sPLA (sPLA $_{2}$-IIA) is often referred to as an inflammatory sPLA $\mathrm{S}_{2}$, since its expression is markedly induced during inflammation, cardiovascular diseases, and tissue damages [78]. When overexpressed, sPLA $_{2}$-IIA is capable of augmenting arachidonic acid release in cytokine-stimulated cells, albeit more weakly than $\mathrm{sPLA}_{2}-\mathrm{V},-\mathrm{X}$ and -III [79]. Despite these facts, the contribution of $\mathrm{SPLA}_{2}$-IIA to inflammation has remained a subject of debate until recently, since a natural mutation of its gene in C57BL/6 and 129Sv mice [80] prevents the proper assessment of its functions by a classical gene targeting strategy. Intrinsic deficiency of sPLA $_{2}$-IIA in these mouse strains is associated with increased incidence of intestinal polyposis and tumorigengesis [80], a phenotype that is reversed by transgenic expression of the Pla2g2a gene [81]. A recent study using Pla2g2a-deficient BALB/c mice as well as Pla2g2a-Tg mice has provided compelling evidence that the enzyme plays an exacerbating role in inflammatory arthritis [26]. The best-recognized physiologic function of sPLA ${ }_{2}$-IIA is the degradation of Gram-positive bacterial membrane, thereby providing the first line of antimicrobial defense of the host [82-85]. The serum level of sPLA 2 -IIA also shows correlation with the risk of cardiovascular diseases [86], and Pla2g2a-Tg mice fed an atherogenic diet developed atherosclerosis [87,88]. This effect is probably because $\mathrm{SPLA}_{2}$-mediated hydrolysis of LDL phospholipids leads to generation of smalldense, pro-atherogenic LDL particles that facilitate macrophage foam cell formation, even though the hydrolytic activity of $\mathrm{sPLA}_{2}$-IIA toward lipoportein particles is much weaker than that of sPLA $2-\mathrm{V},-\mathrm{X}$ and -III. Pla2g2a-Tg mice also displayed permanent alopecia and were susceptible to carcinogeninduced skin tumorigenesis $[39,40]$.

The roles of other group II subfamily sPLA 2 isoforms remain elusive, since knockout or transgenic mice for these enzymes have not yet been reported. sPLA 2 -IIC is expressed in rodent testis, but not in humans [89]. sPLA 2 -IID is structurally most similar to $\mathrm{sPLA}_{2}$-IIA, and its transcript is constitutively detected in the lymphoid organs [90]. This enzyme may have immuno-suppressive functions, since it is expressed in regulatory $\mathrm{T}$ cells and its fusion protein has the ability to suppress inflammatory bowel disease and experimental autoimmune encephalomyelitis in mice [91]. sPLA2-IIE, another group IIA-related enzyme, is expressed constitutively in several tissues at low levels and has a lower catalytic activity than other group II $\mathrm{sPLA}_{2} \mathrm{~s}$ [92]. $\mathrm{sPLA}_{2}$-IIF possesses a unique 30-amino acid C-terminal extension that contains an additional Cys residue, which might contribute to formation of a homodimer or a heterodimer with a second protein $[93,94]$. This enzyme is expressed most abundantly in the skin [100].

Lastly, group XII sPLA ${ }_{2} \mathrm{~s}\left(\mathrm{sPLA}_{2}\right.$-XIIA and -XIIB) represent a unique collection of the $\mathrm{sPLA}_{2}$ family. sPLA 2 -XIIA has the central catalytic domain with a His/Asp catalytic dyad, yet the location of Cys residues outside the catalytic domain is rather distinct from that of other $\mathrm{sPLA}_{2} \mathrm{~S}$ [95]. High 
expression of this enzyme is found in many tissues, although its enzymatic activity is very weak. A study using Xenopus suggests the role of this enzyme in early neuronal development [96]. sPLA ${ }_{2}$ XIIB

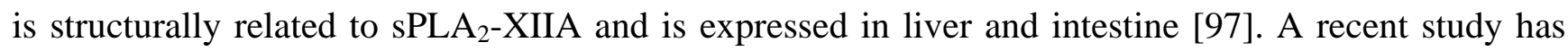
demonstrated that the transcription of Pla2g $12 b$ was regulated by the transcription factor HNF-4 $\alpha$ and its co-activator PGC-1 $\alpha$, and deletion of the Pla2g $12 b$ gene resulted in increased fat accumulation in the liver leading to steatohepatitis, a phenotype similar to that seen in $\mathrm{HnfH}^{-/-}$mice [98]. The aberrant fat accumulation in Pla2g $12 b^{-/-}$liver was ascribed to impaired hepatic secretion of VLDL. However, because sPLA $_{2}$-XIIB lacks the catalytic activity since the catalytic center His is replaced with Leu [97], the molecular mechanism whereby this $\mathrm{sPLA}_{2}$ isoform regulates VLDL secretion remains unknown.

\section{Conclusions}

During the past decade, the biological functions of several $\mathrm{sPLA}_{2} \mathrm{~S}$ and their target substrates have been clarified by studies using transgenic and knockout mice in combination with lipidomics. Nevertheless, full understanding of the biological roles of all sPLA 2 isoforms is still a challenging area of research. The control of particular $\mathrm{SPLA}_{2} \mathrm{~s}$, alone or in combination of multiple isoforms, should have advantages over the inhibition of selective lipid metabolic pathways in the treatment of various diseases. Interestingly, the pan-sPLA 2 inhibitor A-002 (varespladib), which inhibits the conventional class of $\mathrm{sPLA}_{2} \mathrm{~s}$, can markedly reduce the atherosclerotic lesion area in experimental animals and even in humans in early-phase clinical studies [99]. This fact points to the $\mathrm{sPA}_{2}$ family as a potential therapeutic target for atherosclerosis, and probably other diseases in which one or more $\mathrm{SPLA}_{2} \mathrm{~s}$ are involved, such as asthma, arthritis, and metabolic syndrome.

\section{Acknowledgements}

This work was supported by grants-in aid for scientific research from the Ministry of Education, Science, Culture, Sports and Technology of Japan.

\section{References}

1. Uozumi, N.; Kume, K.; Nagase, T.; Nakatani, N.; Ishii, S.; Tashiro, F.; Komagata, Y.; Maki, K.; Ikuta, K.; Ouchi, Y.; Miyazaki, J.; Shimizu, T. Role of cytosolic phospholipase $\mathrm{A}_{2}$ in allergic response and parturition. Nature 1997, 390, 618-622.

2. Kudo, I.; Murakami, M. Phospholipase $\mathrm{A}_{2}$ enzymes. Prostag. Other Lipid Mediat. 2002, 68-69, $3-58$.

3. Lambeau, G.; Gelb, M.H. Biochemistry and physiology of mammalian secreted phospholipases $\mathrm{A}_{2}$. Annu. Rev. Biochem. 2008, 77, 495-520.

4. Murakami, M.; Taketomi, Y.; Girard, C.; Yamamoto, K.; Lambeau, G. Emerging roles of secreted phospholipase $\mathrm{A}_{2}$ enzymes: Lessons from transgenic and knockout mice. Biochimie 2010, 92, 561-582.

5. Chen, J.; Engle, S.J.; Seilhamer, J.J.; Tischfield, J.A. Cloning and recombinant expression of a novel human low molecular weight $\mathrm{Ca}^{2+}$-dependent phospholipase $\mathrm{A}_{2}$. J. Biol. Chem. 1994, 269, $2365-2368$. 
6. Munoz, N.M.; Meliton, A.Y.; Arm, J.P.; Bonventre, J.V.; Cho, W.; Leff, A.R. Deletion of secretory group $\mathrm{V}$ phospholipase $\mathrm{A}_{2}$ attenuates cell migration and airway hyperresponsiveness in immunosensitized mice. J. Immunol. 2007, 179, 4800-4807.

7. Masuda, S.; Murakami, M.; Mitsuishi, M.; Komiyama, K.; Ishikawa, Y.; Ishii, T.; Kudo, I. Expression of secretory phospholipase $\mathrm{A}_{2}$ enzymes in lungs of humans with pneumonia and their potential prostaglandin-synthetic function in human lung-derived cells. Biochem. J. 2005, 387, 27-38.

8. Ohtsuki, M.; Taketomi, Y.; Arata, S.; Masuda, S.; Ishikawa, Y.; Ishii, T.; Takanezawa, Y.; Aoki, J.; Arai, H.; Yamamoto, K.; Kudo, I.; Murakami, M. Transgenic expression of group V, but not group $\mathrm{X}$, secreted phospholipase $\mathrm{A}_{2}$ in mice leads to neonatal lethality because of lung dysfunction. J. Biol. Chem. 2006, 281, 36420-36433.

9. Touqi, L.; Arbibe, L. A role for phospholipase $\mathrm{A}_{2}$ in ARDS pathogenesis. Mol. Med. Today 1999, 5, 244-249.

10. Nag, K.; Munro, J.G.; Inchley, K.; Schürch, S.; Petersen, N.O.; Possmayer, F. SP-B refining of pulmonary surfactant phospholipid films. Am. J. Physiol. 1999, 277, L1179-L1189.

11. Arbibe, L.; Koumanov, K.; Vial, D.; Rougeot, C.; Faure, G.; Havet, N.; Longacre, S.; Vargaftig, B.B.; Béréziat, G.; Voelker, D.R.; Wolf, C.; Touqui, L. Generation of lyso-phospholipids from surfactant in acute lung injury is mediated by type-II phospholipase $\mathrm{A}_{2}$ and inhibited by a direct surfactant protein A-phospholipase $\mathrm{A}_{2}$ protein interaction. J. Clin. Invest 1998, 102, 1152-1160

12. Wu, Y.; Singer, M.; Thouron, F.; Alaoui-El-Azher, M.; Touqui, L. Effect of surfactant on pulmonary expression of type IIA PLA 2 in an animal model of acute lung injury. Am. J. Physiol. Lung. Cell Mol. Physiol. 2002, 282, L743-L750.

13. Wu, Y.Z.; Medjane, S.; Chabot, S.; Kubrusly, F.S.; Raw, I.; Chignard, M.; Touqui, L. Surfactant protein-A and phosphatidylglycerol suppress type IIA phospholipase $\mathrm{A}_{2}$ synthesis via nuclear factor-кB. Am. J. Respir. Crit. Care Med. 2003, 168, 692-699.

14. Wang, Z.; Schwan, A.L.; Lairson, L.L.; O’Donnell, J.S.; Byrne, G.F.; Foye, A.; Holm, B.A.; Notter, R.H. Surface activity of a synthetic lung surfactant containing a phospholipase-resistant phosphonolipid analog of dipalmitoyl phosphatidylcholine. Am. J. Physiol. Lung Cell Mol. Physiol. 2003, 285, L550-L559.

15. Furue, S.; Kuwabara, K.; Mikawa, K.; Nishina, K.; Shiga, M.; Maekawa, N.; Ueno, M.; Chikazawa, Y.; Ono, T.; Hori, Y.; Matsukawa, A.; Yoshinaga, M.; Obara, H. Crucial role of group IIA phospholipase $\mathrm{A}_{2}$ in oleic acid-induced acute lung injury in rabbits. Crit. Care Med. 2001, 29, 719-727.

16. Chabot, S.; Koumanov, K.; Lambeau, G.; Gelb, M.H.; Balloy, V.; Chignard, M.; Whitsett, J.A.; Touqui, L. Inhibitory effects of surfactant protein A on surfactant phospholipid hydrolysis by secreted phospholipases A2. J. Immunol. 2003, 171, 995-1000.

17. Seeds, M.C.; Jones, K.A.; Duncan, H.R.; Willingham, M.C.; Borgerink, H.M.; Woodruff, R.D.; Bowton, D.L.; Bass, D.A. Cell-specific expression of group $\mathrm{X}$ and group $\mathrm{V}$ secretory phospholipases $\mathrm{A}_{2}$ in human lung airway epithelial cells. Am. J. Respir. Cell Mol. Biol. 2000, 23, 37-44. 
18. Hite, R.D.; Seeds, M.C.; Safta, A.M.; Jacinto, R.B.; Gyves, J.I; Bass, D.A.; Waite, B.M. Lysophospholipid generation and phosphatidylglycerol depletion in phospholipase $\mathrm{A}_{2}$-mediated surfactant dysfunction. Am. J. Physiol. Lung Cell Mol. Physiol. 2005, 288, L618-L624.

19. Shulenin, S.; Nogee, L.M.; Annilo, T.; Wert, S.E.; Whitsett, J.A.; Dean, M. ABCA3 gene mutations in newborns with fatal surfactant deficiency. N. Engl. J. Med. 2004, 350, 1296-1303.

20. Bridges, J.P.; Ikegami, M.; Brilli, L.L.; Chen, X.; Mason, R.J.; Shannon, J.M. LPCAT1 regulates surfactant phospholipid synthesis and is required for transitioning to air breathing in mice. J. Clin. Invest. 2010, 120, 1736-1748.

21. Munoz, N.M.; Meliton, A.Y.; Meliton, L.N.; Dudek, S.M.; Leff, A.R. Secretory group V phospholipase $\mathrm{A}_{2}$ regulates acute lung injury and neutrophilic inflammation caused by LPS in mice. Am. J. Physiol. Lung Cell Mol. Physiol. 2009, 296, L879-L887.

22. Giannattasio, G.; Fujioka, D.; Xing, W.; Katz, H.R.; Boyce, J.A.; Balestrieri, B. Group V secretory phospholipase $\mathrm{A}_{2}$ reveals its role in house dust mite-induced allergic pulmonary inflammation by regulation of dendritic cell function. J. Immunol. 2010, 185, 4430-4438.

23. Satake, Y.; Diaz, B.L.; Balestrieri, B.; Lam, B.K.; Kanaoka, Y.; Grusby, M.J.; Arm, J.P. Role of group $\mathrm{V}$ phospholipase $\mathrm{A}_{2}$ in zymosan-induced eicosanoid generation and vascular permeability revealed by targeted gene disruption. J. Biol. Chem. 2004, 279, 16488-16494.

24. Balestrieri, B.; Hsu, V.W.; Gilbert, H.; Leslie, C.C.; Han, W.K.; Bonventre, J.V.; Arm, J.P. Group $\mathrm{V}$ secretory phospholipase $\mathrm{A}_{2}$ translocates to the phagosome after zymosan stimulation of mouse peritoneal macrophages and regulates phagocytosis. J. Biol. Chem. 2006, 281, 6691-6698.

25. Balestrieri, B.; Maekawa, A.; Xing, W.; Gelb, M.H.; Katz, H.R.; Arm, J.P. Group V secretory phospholipase $\mathrm{A}_{2}$ modulates phagosome maturation and regulates the innate immune response against Candida albicans. J. Immunol. 2009, 182, 4891-4898.

26. Boilard, E.; Lai, Y.; Larabee, K.; Balestrieri, B.; Ghomashchi, F.; Fujioka, D.; Gobezie, R.; Coblyn, J.S.; Weinblatt, M.E.; Massarotti, E.M.; Thornhill, T.S.; Divangahi, M.; Remold, H.; Lambeau, G.; Gelb, M.H.; Arm, J.P.; Lee, D.M. A novel anti-inflammatory role for secretory phospholipase $\mathrm{A}_{2}$ in immune complex-mediated arthritis. EMBO Mol. Med. 2010, 2, 172-187.

27. Bostrom, M.A.; Boyanovsky, B.B.; Jordan, C.T.; Wadsworth, M.P.; Taatjes, D.J.; De Beer, F.C.; Webb, N.R. Group V secretory phospholipase $A_{2}$ promotes atherosclerosis: Evidence from genetically altered mice. Arterioscler. Thromb. Vasc. Biol. 2007, 27, 600-606.

28. Wootton, P.T.; Arora, N.L.; Drenos, F.; Thompson, S.R.; Cooper, J.A.; Stephens, J.W.; Hurel, S.J.; Hurt-Camejo, E.; Wiklund, O.; Humphries, S.E.; Talmud, P.J. Tagging SNP haplotype analysis of the secretory PLA $_{2}-\mathrm{V}$ gene, PLA2G5, shows strong association with LDL and oxLDL levels, suggesting functional distinction from sPLA 2 -IIA: Results from the UDACS study. Hum. Mol. Genet. 2007, 16, 1437-1444.

29. Cupillard, L.; Koumanov, K.; Mattéi, M.G.; Lazdunski, M.; Lambeau, G. Cloning, chromosomal mapping, and expression of a novel human secretory phospholipase $\mathrm{A}_{2}$. J. Biol. Chem. 1997, 272, 15745-15752.

30. Murakami, M.; Koduri, R.S.; Enomoto, A.; Shimbara, S.; Seki, M.; Yoshihara, K.; Singer, A.; Valentin, E.; Ghomashchi, F.; Lambeau, G.; Gelb, M.H.; Kudo, I. Distinct arachidonate-releasing functions of mammalian secreted phospholipases $\mathrm{A}_{2}$ in fibroblastic and mastocytoma cells 
through heparan sulfate shuttling and external plasma membrane mechanisms. J. Biol. Chem. 2001, 276, 10083-10096.

31. Bezzine, S.; Koduri, R.S.; Valentin, E.; Murakami, M.; Kudo, I.; Ghomashchi, F.; Sadilek, M.; Lambeau, G.; Gelb, M.H. Exogenously added human group X secreted phospholipase $\mathrm{A}_{2}$ but not the group IB, IIA, and V enzymes efficiently release arachidonic acid from adherent mammalian cells. J. Biol. Chem. 2000, 275, 3179-3191.

32. Escoffier, J.; Jemel, I.; Tanemoto, A.; Taketomi, Y.; Payre, C.; Coatrieux, C.; Sato, H.; Yamamoto, K.; Masuda, S.; Pernet-Gallay, K.; Pierre, V.; Hara, S.; Murakami, M.; De Waard, M.; Lambeau, G.; Arnoult, C. Group X phospholipase $\mathrm{A}_{2}$ is released during sperm acrosome reaction and controls fertility outcome in mice. J. Clin. Invest 2010, 120, 1415-1428.

33. Sato, H.; Isogai, Y.; Masuda, S.; Taketomi, Y.; Miki, Y.; Kamei, D.; Hara, S.; Kobayashi, T.; Ishikawa, Y.; Ishii, T.; Ikeda, K.; Taguchi, R.; Ishimoto, Y.; Suzuki, N.; Yokota, Y.; Hanasaki, K.; Suzuki-Yamamoto, T.; Yamamoto, K.; Murakami, M. Physiological roles of group X secreted phospholipase $\mathrm{A}_{2}$ in reproduction, gastrointestinal phospholipid digestion, and neuronal function. J. Biol. Chem. 2011, in press.

34. Henderson, W.R., Jr.; Chi, E.Y.; Bollinger, J.G.; Tien, Y.T.; Ye, X.; Castelli, L.; Rubtsov, Y.P.; Singer, A.G.; Chiang, G.K.; Nevalainen, T.; Rudensky, A.Y.; Gelb, M.H. Importance of group $\mathrm{X}$-secreted phospholipase $\mathrm{A}_{2}$ in allergen-induced airway inflammation and remodeling in a mouse asthma model. J. Exp. Med. 2007, 204, 865-877.

35. Hallstrand, T.S.; Chi, E.Y.; Singer, A.G.; Gelb, M.H.; Henderson, W.R., Jr. Secreted phospholipase $\mathrm{A}_{2}$ group $\mathrm{X}$ overexpression in asthma and bronchial hyperresponsiveness. Am. J. Respir. Crit. Care Med. 2007, 176, 1072-1078.

36. Fujioka, D.; Saito, Y.; Kobayashi, T.; Yano, T.; Tezuka, H.; Ishimoto, Y.; Suzuki, N.; Yokota, Y.; Nakamura, T.; Obata, J.E.; Kanazawa, M.; Kawabata, K.; Hanasaki, K.; Kugiyama, K. Reduction in myocardial ischemia/reperfusion injury in group $\mathrm{X}$ secretory phospholipase $\mathrm{A}_{2}$ deficient mice. Circulation 2008, 117, 2977-2985.

37. Curfs, D.M.; Ghesquiere, S.A.; Vergouwe, M.N.; Van der Made, I.; Gijbels, MJ.; Greaves, D.R.; Verbeek, J.S.; Hofker, M.H.; De Winther, M.P. Macrophage secretory phospholipase $\mathrm{A}_{2}$ group X enhances anti-inflammatory responses, promotes lipid accumulation, and contributes to aberrant lung pathology. J. Biol. Chem. 2008, 283, 21640-21648.

38. Yamamoto, K.; Taketomi, T.; Isogai, Y.; Miki, Y.; Sato, H.; Masuda, S.; Nishito, Y.; Morioka, K.; Ishimoto, Y.; Suzuki, N.; Yokoya, Y.; Hanasaki, K.; Ishikawa, Y.; Ishii, T.; Kobayashi, T.; Fukami, K.; Ikeda, K.; Nakanishi, H.; Taguchi, R.; Murakami, M. Hair follicular expression and function of group X secreted phospholipase $\mathrm{A}_{2}$ in mouse skin. J. Biol. Chem. 2011, in press.

39. Grass, D.S.; Felkner, R.H.; Chiang, M.Y.; Wallace, R.E.; Nevalainen, T.J.; Bennett, C.F.; Swanson, M.E. Expression of human group II PLA $\mathrm{PL}_{2}$ in transgenic mice results in epidermal hyperplasia in the absence of inflammatory infiltrate. J. Clin. Invest 1996, 97, 2233-2241.

40. Mulherkar, R.; Kirtane, B.M.; Ramchandani, A.; Mansukhani, N.P.; Kannan, S.; Naresh, K.N. Expression of enhancing factor/phospholipase $\mathrm{A}_{2}$ in skin results in abnormal epidermis and increased sensitivity to chemical carcinogenesis. Oncogene 2003, 22, 1936-1944. 
41. Hanasaki, K.; Yamada, K.; Yamamoto, S.; Ishimoto, Y.; Saiga, A.; Ono, T.; Ikeda, M.; Notoya, M.; Kamitani, S.; Arita, H. Potent modification of low density lipoprotein by group X secretory phospholipase $\mathrm{A}_{2}$ is linked to macrophage foam cell formation. J. Biol. Chem. 2002, 277, 29116-29124.

42. Zack, M.; Boyanovsky, B.B.; Shridas, P.; Bailey, W.; Forrest, K.; Howatt, D.A.; Gelb, M.H.; De Beer, F.C.; Daugherty, A.; Webb, N.R. Group X secretory phospholipase $\mathrm{A}_{2}$ augments angiotensin II-induced inflammatory responses and abdominal aortic aneurysm formation in apoE-deficient mice. Atherosclerosis 2010, in press.

43. Shridas, P.; Bailey, W.M.; Gizard, F.; Oslund, R.C.; Gelb, M.H.; Bruemmer, D.; Webb, N.R. Group X secretory phospholipase $\mathrm{A}_{2}$ negatively regulates ABCA1 and ABCG1 expression and cholesterol efflux in macrophages. Arterioscler Thromb. Vasc. Biol. 2010, 30, 2014-2021.

44. Shridas, P.; Bailey, W.M.; Boyanovsky, B.B.; Oslund, R.C.; Gelb, M.H.; Webb, N.R. Group X secretory phospholipase $\mathrm{A}_{2}$ regulates the expression of steroidogenic acute regulatory protein (StAR) in mouse adrenal glands. J. Biol. Chem. 2010, 285, 20031-20039.

45. Li, X.; Shridas, P.; Forrest, K.; Bailey, W.; Webb, N.R. Group X secretory phospholipase $\mathrm{A}_{2}$ negatively regulates adipogenesis in murine models. FASEB J. 2010, 24, 4313-4324.

46. Valentin, E.; Ghomashchi, F.; Gelb, M.H.; Lazdunski, M.; Lambeau, G. Novel human secreted phospholipase $\mathrm{A}_{2}$ with homology to the group III bee venom enzyme. J. Biol. Chem. 2000, 275, 7492-7496.

47. Murakami, M.; Masuda, S.; Shimbara, S.; Bezzine, S.; Lazdunski, M.; Lambeau, G.; Gelb, M.H.; Matsukura, S.; Kokubu, F.; Adachi, M.; Kudo, I. Cellular arachidonate-releasing function of novel classes of secretory phospholipase $\mathrm{A}_{2} \mathrm{~s}$ (groups III and XII). J. Biol. Chem. 2003, 278, 10657-10667.

48. Murakami, M.; Masuda, S.; Shimbara, S.; Ishikawa, Y.; Ishii, T.; Kudo, I. Cellular distribution, post-translational modification, and tumorigenic potential of human group III secreted phospholipase A2. J. Biol. Chem. 2005, 280, 24987-24998.

49. Masuda, S.; Yamamoto, K.; Hirabayashi, T.; Ishikawa, Y.; Ishii, T.; Kudo, I.; Murakami, M. Human group III secreted phospholipase $\mathrm{A}_{2}$ promotes neuronal outgrowth and survival. Biochem. J. 2008, 409, 429-438.

50. Mounier, C.M.; Wendum, D.; Greenspan, E.; Flejou, J.F.; Rosenberg, D.W.; Lambeau, G. Distinct expression pattern of the full set of secreted phospholipases $\mathrm{A}_{2}$ in human colorectal adenocarcinomas: sPLA 2 -III as a biomarker candidate. Br. J. Cancer 2008, 98, 587-595.

51. Sato, H.; Taketomi, Y.; Isogai, Y.; Masuda, S.; Kobayashi, T.; Yamamoto, K.; Murakami, M. Group III secreted phospholipase $\mathrm{A}_{2}$ transgenic mice spontaneously develop inflammation. Biochem. J. 2009, 421, 17-27.

52. Emoto, K.; Inadome, H.; Kanaho, Y.; Narumiya, S.; Umeda, M. Local change in phospholipid composition at the cleavage furrow is essential for completion of cytokinesis. J. Biol. Chem. 2005, 280, 37901-37907.

53. Miyanishi, M.; Tada, K.; Koike, M.; Uchiyama, Y.; Kitamura, T.; Nagata, S. Identification of Tim4 as a phosphatidylserine receptor. Nature 2007, 450, 435-439. 
54. Olson, E.D.; Nelson, J.; Griffith, K.; Nguyen, T.; Streeter, M.; Wilson-Ashworth, H.A.; Gelb, M.H.; Judd, A.M.; Bell, J.D. Kinetic evaluation of cell membrane hydrolysis during apoptosis by human isoforms of secretory phospholipase A2. J. Biol. Chem. 2010, 285, 10993-11002.

55. Sato, H.; Kato, R.; Isogai, Y.; Saka, G.; Ohtsuki, M.; Taketomi, Y.; Yamamoto, K.; Tsutsumi, K.; Yamada, J.; Masuda, S.; Ishikawa, Y.; Ishii, T.; Kobayashi, T.; Ikeda, K.; Taguchi, R.; Hatakeyama, S.; Hara, S.; Kudo, I.; Itabe, H.; Murakami, M. Analyses of group III secreted phospholipase $\mathrm{A}_{2}$ transgenic mice reveal potential participation of this enzyme in plasma lipoprotein modification, macrophage foam cell formation, and atherosclerosis. J. Biol. Chem. 2008, 283, 33483-33497.

56. Kimura-Matsumoto, M.; Ishikawa, Y.; Komiyama, K.; Tsuruta, T.; Murakami, M.; Masuda, S.; Akasaka, Y.; Ito, K.; Ishiguro, S.; Morita, H.; Sato, S.; Ishii, T. Expression of secretory phospholipase $\mathrm{A}_{2} \mathrm{~S}$ in human atherosclerosis development. Atherosclerosis 2008, 196, 81-91.

57. Sato, H.; Taketomi, Y.; Isogai, Y.; Miki, Y.; Yamamoto, K.; Masuda, S.; Hosono, T.; Arata, S.; Ishikawa, Y.; Ishii, T.; Kobayashi, T.; Nakanishi, H.; Ikeda, K.; Taguchi, R.; Hara, S.; Kudo, I.; Murakami, M. Group III secreted phospholipase $\mathrm{A}_{2}$ regulates epididymal sperm maturation and fertility in mice. J. Clin. Invest 2010, 120, 1400-1414.

58. Cooper, T.G. Role of the epididymis in mediating changes in the male gamete during maturation. Adv. Exp. Med. Biol. 1995, 377, 87-101.

59. Rejraji, H.; Sion, B.; Prensier, G.; Carreras, M.; Motta, C.; Frenoux, J.M.; Vericel, E.; Grizard, G.; Vernet, P.; Drevet, J.R. Lipid remodeling of murine epididymosomes and spermatozoa during epididymal maturation. Biol. Reprod. 2006, 74, 1104-1113.

60. Lenzi, A.; Picardo, M.; Gandini, L.; Dondero, F. Lipids of the sperm plasma membrane: from polyunsaturated fatty acids considered as markers of sperm function to possible scavenger therapy. Hum. Reprod. 1996, 2, 246-256.

61. Lenzi, A.; Gandini, L.; Maresca, V.; Rago, R.; Sgrò, P.; Dondero, F.; Picardo, M. Fatty acid composition of spermatozoa and immature germ cells. Mol. Hum. Reprod. 2000, 6, 226-231.

62. Furimsky, A.; Vuong, N.; Xu, H.; Kumarathasan, P.; Xu, M.; Weerachatyanukul, W.; Bou, K.M.; Kates, M.; Tanphaichitr, N. Percoll gradient-centrifuged capacitated mouse sperm have increased fertilizing ability and higher contents of sulfogalactosylglycerolipid and docosahexaenoic acid-containing phosphatidylcholine compared to washed capacitated mouse sperm. Biol. Reprod. 2005, 72, 574-583.

63. Aksoy, Y.; Aksoy, H.; Altinkaynak, K.; Aydin, H.R.; Ozkan, A. Sperm fatty acid composition in subfertile men. Prostag. Leuk. Essent. Fatty 2006, 75, 75-79.

64. Hall, J.C.; Hadley, J.; Doman, T. Correlation between changes in rat sperm membrane lipids, protein, and the membrane physical state during epididymal maturation. J. Androl. 1991, 12, 76-87.

65. Haidl, G.; Opper, C. Changes in lipids and membrane anisotropy in human spermatozoa during epididymal maturation. Hum. Reprod. 1997, 12, 2720-2723.

66. Fischer, K.A.; Van Leyen, K.; Lovercamp, K.W.; Manandhar, G.; Sutovsky, M.; Feng, D.; Safranski, T.; Sutovsky, P. 15-Lipoxygenase is a component of the mammalian sperm cytoplasmic droplet. Reproduction 2005, 130, 213-222. 
67. Law, G.L.; McGuinness, M.P.; Linder, C.C.; Griswold, M.D. Expression of apolipoprotein E mRNA in the epithelium and interstitium of the testis and the epididymis. J. Androl. 1997, 18, $32-42$.

68. Hermo, L.; Wright, J.; Oko, R.; Morales, C.R. Role of epithelial cells of the male excurrent duct system of the rat in the endocytosis or secretion of sulfated glycoprotein-2 (clusterin). Biol. Reprod. 1991, 44, 1113-1131.

69. Huang, L.S.; Voyiaziakis, E.; Chen, H.L.; Rubin, E.M.; Gordon, J.W. A novel functional role for apolipoprotein B in male infertility in heterozygous apolipoprotein B knockout mice. Proc. Natl. Acad. Sci. USA 1996, 93, 10903-10907.

70. Moghadasian, M.H.; Nguyen, L.B.; Shefer, S.; McManus, B.M.; Frohlich, J.J. Histologic, hematologic, and biochemical characteristics of apo E-deficient mice: effects of dietary cholesterol and phytosterols. Lab. Invest 1999, 79, 355-364.

71. Andersen, O.M.; Yeung, C.H.; Vorum, H.; Wellner, M.; Andreassen, T.K.; Erdmann, B.; Mueller, E.C.; Herz, J.; Otto, A.; Cooper, T.G.; Willnow, T.E. Essential role of the apolipoprotein E receptor-2 in sperm development. J. Biol. Chem. 2003, 278, 23989-23995.

72. Saez, F.; Frenette, G.; Sullivan, R. Epididymosomes and prostasomes: their roles in posttesticular maturation of the sperm cells. J. Androl 2003, 24, 149-154.

73. Masuda, S.; Murakami, M.; Matsumoto, S.; Eguchi, N.; Urade, Y.; Lambeau, G.; Gelb, M.H.; Ishikawa, Y.; Ishii, T.; Kudo, I. Localization of various secretory phospholipase $\mathrm{A}_{2}$ enzymes in male reproductive organs. Biochim. Biophys. Acta 2004, 1686, 61-76.

74. Seilhamer, J.J.; Randall, T.L.; Yamanaka, M.; Johnson, L.K. Pancreatic phospholipase $\mathrm{A}_{2}$ : Isolation of the human gene and cDNAs from porcine pancreas and human lung. DNA 1986, 5, 519-527.

75. Labonte, E.D.; Kirby, R.J.; Schildmeyer, N.M.; Cannon, A.M.; Huggins, K.W.; Hui, D.Y. Group IB phospholipase $\mathrm{A}_{2}$-mediated lysophospholipid absorption directly contributes to postprandial hyperglycemia. Diabetes 2006, 55, 935-941.

76. Hui, D.Y.; Cope, M.J.; Labonte, E.D.; Chang, H.T.; Shao, J.; Goka, E.; Abousalham, A.; Charmot, D.; Buysse, J. The phospholipase $\mathrm{A}_{2}$ inhibitor methyl indoxam suppresses diet-induced obesity and glucose intolerance in mice. Br. J. Pharmacol. 2009, 157, 1263-1269.

77. Wilson, S.G.; Adam, G.; Langdown, M.; Reneland, R.; Braun, A.; Andrew, T.; Surdulescu, G.L.; Norberg, M.; Dudbridge, F.; Reed, P.W.; Sambrook, P.N.; Kleyn, P.W.; Spector, T.D. Linkage and potential association of obesity-related phenotypes with two genes on chromosome 12q24 in a female dizygous twin cohort. Eur. J. Hum Genet 2006, 14, 340-348.

78. Pruzanski, W.; Vadas, P. Phospholipase $\mathrm{A}_{2}-\mathrm{A}$ mediator between proximal and distal effectors of inflammation. Immunol. Today 1991, 12, 143-146.

79. Murakami, M.; Kambe, T.; Shimbara, S.; Yamamoto S, Kuwata H, Kudo I. Functional association of type IIA secretory phospholipase $\mathrm{A}_{2}$ with the glycosylphosphatidylinositol-anchored heparan sulfate proteoglycan in the cyclooxygenase-2-mediated delayed prostanoid-biosynthetic pathway. J. Biol. Chem. 1999, 274, 29927-29936.

80. MacPhee, M.; Chepenik, P.K.; Liddel, A.R.; Nelson, K.K.; Siracusa, D.L.; Buchberg, M.A. The secretory phospholipase $\mathrm{A}_{2}$ gene is a candidate for the Moml locus, a major modifier of $A p c^{\text {min }}$-induced intestinal neoplasia. Cell 1995, 81, 957-966. 
81. Cormier, R.T.; Hong, K.H.; Halberg, R.B.; Hawkins, T.L.; Richardson, P.; Mulherkar, R.; Dove, W.F.; Lander, E.S. Secretory phospholipase Pla2g2a confers resistance to intestinal tumorigenesis. Nat. Genet 1997, 17, 88-91.

82. Weinrauch, Y.; Elsbach, P.; Madsen, L.M.; Foreman, A.; Weiss, J. The potent anti-Staphylococcus aureus activity of a sterile rabbit inflammatory fluid is due to a $14-\mathrm{kD}$ phospholipase $\mathrm{A}_{2}$. J. Clin. Invest 1996, 97, 250-257.

83. Weinrauch, Y.; Abad, C.; Liang, N.S.; Lowry, S.F.; Weiss, J. Mobilization of potent plasma bactericidal activity during systemic bacterial challenge. Role of group IIA phospholipase $\mathrm{A}_{2}$. J. Clin. Invest 1998, 102, 633-638.

84. Laine, V.J.; Grass, D.S.; Nevalainen, T.J. Protection by group II phospholipase $\mathrm{A}_{2}$ against Staphylococcus aureus. J. Immunol. 1999, 162, 7402-7408.

85. Koduri, R.S.; Grönroos, J.O.; Laine, V.J.; Le Calvez, C.; Lambeau, G.; Nevalainen, T.J.; Gelb, M.H. Bactericidal properties of human and murine groups I, II, V, X, and XII secreted phospholipases A 2. J. Biol. Chem. 2002, 277, 5849-5857.

86. Kugiyama, K.; Ota, Y.; Takazoe, K.; Moriyama, Y.; Kawano, H.; Miyao, Y.; Sakamoto, T.; Soejima, H.; Ogawa, H.; Doi, H.; Sugiyama, S.; Yasue, H. Circulating levels of secretory type II phospholipase $\mathrm{A}_{2}$ predict coronary events in patients with coronary artery disease. Circulation 1999, 100, 1280-1284.

87. Ivandic, B.; Castellani, L.W.; Wang, X.P.; Qiao, J.H.; Mehrabian, M.; Navab, M.; Fogelman, A.M.; Grass, D.S.; Swanson, M.E.; De Beer, M.C.; De Beer, F.; Lusis, A.J. Role of group II secretory phospholipase $\mathrm{A}_{2}$ in atherosclerosis: 1. Increased atherogenesis and altered lipoproteins in transgenic mice expressing group IIa phospholipase $\mathrm{A}_{2}$. Arterioscler. Thromb. Vasc. Biol. 1999, 19, 1284-1290.

88. Webb, N.R.; Bostrom, M.A.; Szilvassy, S.J.; Van der Westhuyzen, D.R.; Daugherty, A.; De Beer, F.C. Macrophage-expressed group IIA secretory phospholipase $\mathrm{A}_{2}$ increases atherosclerotic lesion formation in LDL receptor-deficient mice. Arterioscler. Thromb. Vasc. Biol. 2003, 23, 263-268.

89. Chen, J.; Shao, C.; Lazar, V.; Srivastava, C.H.; Lee, W.H.; Tischfield, J.A. Localization of group IIc low molecular weight phospholipase $\mathrm{A}_{2}$ mRNA to meiotic cells in the mouse. J. Cell Biochem. 1997, 64, 369-375.

90. Shakhov, A.N.; Rubtsov, A.V.; Lyakhov, I.G.; Tumanov, A.V.; Nedospasov, S.A. SPLASH (PLA $\mathrm{P}_{2} \mathrm{IID}$ ), a novel member of phospholipase $\mathrm{A}_{2}$ family, is associated with lymphotoxin deficiency. Genes Immun. 2000, 1, 191-199.

91. Von Allmen, C.E.; Schmitz, N.; Bauer, M.; Hinton, H.J.; Kurrer, M.O.; Buser, R.B.; Gwerder, M.; Muntwiler, S.; Sparwasser, T.; Beerli, R.R.; Bachmann, M.F. Secretory phospholipase $\mathrm{A}_{2}$-IID is an effector molecule of CD4+CD25+ regulatory T cells. Proc. Natl. Acad. Sci. USA 2009, 106, 11673-11678.

92. Suzuki, N.; Ishizaki, J.; Yokota, Y.; Higashino, K.; Ono, T.; Ikeda, M.; Fujii, N.; Kawamoto, K.; Hanasaki, K. Structures, enzymatic properties, and expression of novel human and mouse

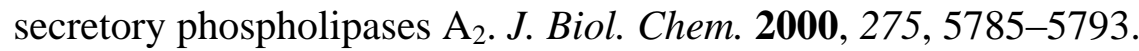


93. Valentin, E.; Ghomashchi, F.; Gelb, MH.; Lazdunski, M.; Lambeau, G. On the diversity of secreted phospholipases $\mathrm{A}_{2}$. Cloning, tissue distribution, and functional expression of two novel mouse group II enzymes. J. Biol. Chem. 1999, 274, 31195-31202.

94. Murakami, M.; Yoshihara, K.; Shimbara, S.; Lambeau, G.; Gelb, M.H.; Singer, A.G.; Sawada, M.; Inagaki, N.; Nagai, H.; Ishihara, M.; Ishikawa, Y.; Ishii, T.; Kudo, I. Cellular arachidonate-releasing function and inflammation-associated expression of group IIF secretory phospholipase $\mathrm{A}_{2} . J$. Biol. Chem. 2002, 277, 19145-19155.

95. Gelb, M.H.; Valentin, E.; Ghomashchi, F.; Lazdunski, M.; Lambeau, G. Cloning and recombinant expression of a structurally novel human secreted phospholipase $\mathrm{A}_{2}$. J. Biol. Chem. 2000, 275, 39823-39826.

96. Munoz-Sanjuan, I.; Brivanlou, A.H. Induction of ectopic olfactory structures and bone morphogenetic protein inhibition by Rossy, a group XII secreted phospholipase $\mathrm{A}_{2}$. Mol. Cell Biol. 2005, 25, 3608-3619.

97. Rouault, M.; Bollinger, J.G.; Lazdunski, M.; Gelb, M.H.; Lambeau, G. Novel mammalian group XII secreted phospholipase $A_{2}$ lacking enzymatic activity. Biochemistry 2003, 42, 11494-11503.

98. Guan, M.; Qu, L.; Tan, W.; Chen, L.; Wong, C.W. Hepatocyte nuclear factor-4 $\alpha$ regulates liver triglyceride metabolism in part through secreted phospholipase $\mathrm{A}_{2}$ GXIIB. Hepatology 2011, in press.

99. Rosenson, R.S. Phospholipase $\mathrm{A}_{2}$ inhibition and atherosclerotic vascular disease: prospects for targeting secretory and lipoprotein-associated phospholipase $\mathrm{A}_{2}$ enzymes. Curr. Opin. Lipidol. 2010, 21, 473-480.

100. Yamamoto, K.; Takemomi, Y.; Miki, Y.; Shimo, K.; Nakanishi, H.; Ikeda, K.; Taguchi, R.; Gelb, M.H.; Murakami, M. The Tokyo Metropolitan Institute of Medical Science, Tokyo, Japan, 2010, unpublished results.

(C) 2011 by the authors; licensee MDPI, Basel, Switzerland. This article is an open access article distributed under the terms and conditions of the Creative Commons Attribution license (http://creativecommons.org/licenses/by/3.0/). 